\title{
ENRIQUECENDO COM O DIDI: NO GARIMPO DE UMA PEDRA DE TOQUE PARA A INDÚSTRIA BRASILEIRA DE LOCALIZAÇÃO DE VIDEOGAMES
}

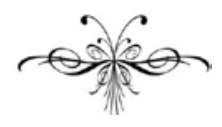

ROBERTO MÁRIO SCHRAMM JR.

Resumo: O fenômeno da localização está para o produto assim como o da tradução está para o texto. Acredito que conceitos como global e internacional devam ser empregados com cautela no contexto da localização de produtos. Minha tese: não existe um produto global; produtos ou serviços apenas se internacionalizam quando se localizam, quando se replicam em outras praças e mercados para além de sua praça de inserção primeira. Há sempre restrições operando sobre o processo de localização. A localização brasileira do videogame Didi na mina encantada parece desafiar o postulado das restrições. Ademais, o lançamento desse jogo, em 1983, marca o primeiro processo significativo de localização de um videogame no Brasil. Analisando essa questão, somos confrontados com o fato de que nenhum processo de localização se revela à revelia da sua historicidade. Em nosso estudo de caso, a análise histórica da localização brasileira de Didi na mina encantada descreve um vínculo entre a questão do garimpo em Serra Pelada e os princípios da indústria dos videogames no Brasil. Esse vínculo se dá pelas implicações desse processo de localização que estudamos.

Palavras-chave: Localização de games: Philips Odyssey. Didi na mina encantada. Os Trapalhões. Serra Pelada.

\begin{abstract}
The localization phenomenon is related to products, much in the same way as translation is related to texts. I believe that concepts such as global and international should be employed with caution in the context of localization. My thesis: there is no such thing as a global product; products and services become international insomuch as they are relocated in a new market place. There always are restrictions on localization. The Brazilian localization of the video game Pick Axe Pete for the Magnavox Odissey2 seems to be an exception to this restriction rule. Moreover, the 1983 localization of this game was the first real effort of that nature in the Brazilian video game industry. When analyzing such a state of affairs one is confronted with the fact that the localization phenomenon can hardly be understood regardless of history. In our case study, the historical analysis of the Brazilian localization of Pick Axe Pete allows us to contemplate a connection between the social problems of gold prospection in Serra Pelada, and the beginnings of the Brazilian video game industry. The localization process itself implies the connection.
\end{abstract}

Keywords: Game Localization: Magnavox Odyssey 2. Pick Axe Pete. Os Trapalhões. Serra Pelada. 
$\mathrm{D}$ iscutiremos um possível marco zero da indústria de localização de videogames no Brasil. Essa indústria encontra-se em ritmo de pleno crescimento, proporcionando retornos consideráveis para as grandes produtoras internacionais. Tais produtoras estão descobrindo o mercado brasileiro na mesma medida em que vão caindo por terra alguns arraigados preconceitos, disseminados também entre os fabricantes de hardware e empresas de software comercial. Já houve, de fato, um silencioso consenso entre tais companhias, que desqualificava o mercado brasileiro como uma terra de ninguém, dominada pela pirataria e pelo protecionismo, ou ainda como uma praça mais propícia à desova de tecnologias obsoletas do que ao lançamento e desenvolvimento de novos produtos.

Os tempos são outros então? Mais ou menos! Com a adaptação de alguns de seus produtos às demandas do mercado brasileiro, diversos setores da indústria de tecnologia entenderam que havia uma demanda reprimida por produtos acessíveis, documentados e suportados em língua portuguesa. Perceba-se que muitos produtos, jogos e aplicativos de sucesso mundial circulavam no Brasil, apenas entre uma elite anglófila/anglófona: menos bucaneira digital por vocação do que por ocasião. A ocasião fez o ladrão: o vácuo de lançamentos favoreceu os instintos corsários de quem possuía os meios de navegar pelas docas sem lei de alguma Pirate Bay.

Figura 1 -

A baía dos piratas:

logotipo do sítio

agregador de bittorrents,

The Pirate Bay, refúgio dos bucaneiros digitais.

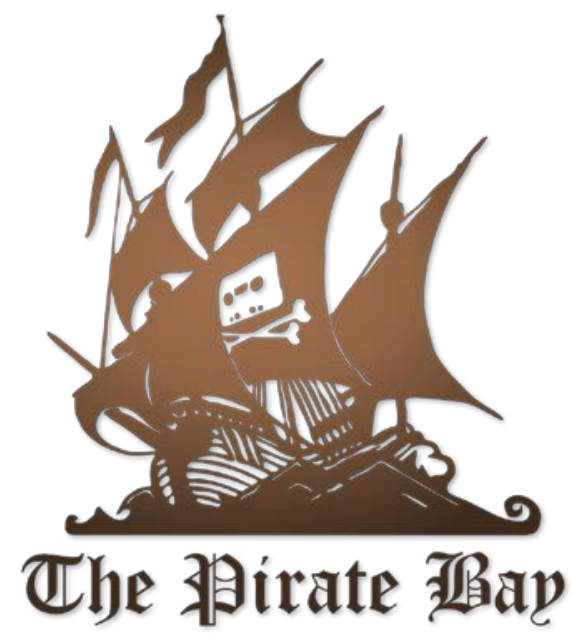

Ora, se a pirataria digital eficaz demanda a mesma competência linguística ${ }^{1}$ necessária para decifrar, por exemplo, algum dos mmorpgs ${ }^{2}$ contemporâneos, podemos ponderar que existe por outro lado um imenso número de pessoas excluídas tanto da possibilidade de utilizar do produto em idioma estrangeiro como também de obtê-lo de forma "honesta".

\footnotetext{
${ }^{1}$ Em língua inglesa principalmente. A pirataria digital é internacional e não prescinde da língua franca. Outros idiomas relevantes? Especulativamente: russo, chinês, espanhol, português, neerlandês...

${ }^{2}$ Massively multiplayer online role-playing games. Os mais importantes, como o World of Warcraft, já estão localizados em língua portuguesa.
} 
Limitaremos nossas considerações à indústria de videogames no Brasil, que já conta mais de três décadas e se encontra consolidada, a despeito dos altos e baixos da economia do país, e das oscilações e crises desencadeadas no interior do próprio setor ${ }^{3}$. Nosso argumento: levando-se em consideração que os jogos se tornaram cada vez mais complexos e que as exigências de competências linguísticas sobre seus jogadores foram igualmente crescendo tanto em termos da 'jogabilidade' e do entendimento da narrativa quanto do ponto de vista do material paratextual que esclarece e contextualiza o jogo, percebemos que ao longo dessas três décadas - no mercado periférico que é o brasileiro, incapaz de produzir senão uma pequena parte dos produtos culturais que consome - prevaleceu na indústria de videogames quem percebeu que havia uma imensa quantidade de consumidores que não estava disposto a enfrentar os desafios linguísticos e culturais impostos pelo produto disponibilizado em idioma estrangeiro.

Há um mercado consistente e crescente para videogames no Brasil. Esse mercado tem como base um público muito vasto e diversificado. Um segmento importante desse público é formado por jovens profissionais especializados e de alto poder aquisitivo que atua em áreas, por vezes, pouco associadas à tecnologia, e que se vê perfeitamente confortável em seu monolinguismo. De monta também há o segmento familiar, que nos parece menos propenso ao domínio de um idioma estrangeiro. Esses segmentos dependem do produto localizado. Assim como apreciam e se posicionam sobre a qualidade da localização, rejeitam o produto “pirata” não-localizado e valorizam o produto "original", na medida em que a origem do produto possa-lhes fornecer suporte e localização em contrapartida. Nesse ponto, podemos dizer que a indústria e o mercado de localização de videogames no Brasil quase que se confundem com a indústria e o mercado de videogames em si - ainda mais se lembrarmos que, salvo raríssimas exceções, o Brasil não desenvolveu propriedades intelectuais significativas no setor.

\footnotetext{
${ }^{3}$ Eu me refiro aqui, principalmente, ao mercado de consoles, que sofreu com diversas e sucessivas crises nos anos 1980 e 1990. Tais crises foram desencadeadas pela própria indústria, e se deveram à questão dos ciclos de vida muito curtos dos consoles, ao excesso de jogos, ao esgotamento da base instalada e à constante entrada de novos concorrentes. Fatores externos alimentaram essas crises, tais como as concorrências com outros suportes para videogames e com outras formas de entretenimento. A primeira grande crise é um exemplo disso: o célebre crash de 1983 (voltaremos a ele) foi gerado, em parte, pela ascensão de microcomputadores com preços acessíveis que podiam executar com vantagens os jogos oferecidos. Por outro lado, esses fatores externos eram frequentemente advindos de um campo muito próximo daquele da indústria de consoles (o dos microcomputadores) ou resultavam de operações de empresas que também fabricavam videogames (e.g., a empresa Mattel fabricava brinquedos que concorriam com o seu console Intellvision, etc.). Sempre haverá qualquer coisa de canibalístico nesse mercado. Hoje em dia, inclusive, a maioria dos pioneiros da indústria de consoles abandonou o setor (e.g., Atari e Sega); alguns resistem com bravura (Nintendo); e os dois gigantes que dominam o mercado são justamente advindos das indústrias vizinhas às quais eu me referia: a Microsoft é uma gigante do software para PCs, enquanto a Sony é uma gigante dos eletro-eletrônicos. A estabilidade do setor, contudo, deu-se na medida em que se aprendeu a administrar os curtos ciclos de vida dos consoles; por meio da necessidade de relançamento sucessivo de novas "gerações" de consoles mais sofisticados; e, por um outro lado, pelo reposicionamento das gerações obsoletas em novas praças e segmentos do mercado consumidor com menor poder aquisitivo. Para uma visão mais aprofundada desse panorama recomendo a leitura do livro de Steven Kent, The ultimate history of videogames: from Pong to Pokemon (ver Referências).
} 
A indústria dos videogames percebeu uma vantagem comparativa na demanda de segmentos no mercado brasileiro por localização. Caso contrário, não se teria investido nessa empreitada. Localizar exige a mobilização de talentos tão diversos quanto específicos. A localização é dispendiosa, como tudo que demanda talento, especificação e diversidade. Para justificar tal investimento é evidente que um grande potencial foi detectado desde as ações pioneiras dos anos 1980. Nesse sentido, pode se dizer que o potencial do produto localizado foi o que salvou o mercado brasileiro da condição de baía dos piratas. Foi ele que, afinal, viabilizou a indústria de videogames no Brasil. Foi o produto localizado que, desde o começo, gerou dividendos para as companhias (americanas, japonesas e europeias) detentoras dos copyrights, que promovem o licenciamento dos jogos e plataformas, ou os comercializam diretamente por meio de suas subsidiárias locais.

O videogame localizado no Brasil é o videogame que vende pelas vias legais, que proporciona retorno ao licenciador. Piratas não pagam royalties. Meros importadores não se importam com a localização. Indiferença ao produto localizado, como se poderia esperar, é um fator que inibe o estabelecimento da indústria, porque resulta de uma dificuldade, por parte do proprietário, em diferenciar o seu produto do produto pirata. A demanda por localização, nesse sentido, é o que favorece a implantação das duas indústrias: videogames e localização de videogames. As matrizes não localizam porque querem; elas localizam porque precisam, devido à exigência dos mercados locais, quando o volume de negócios justifica tal investimento.

Decorrente da necessidade de atendimento da demanda por localização surge um mercado brasileiro de localização, esse sim dominado por companhias nacionais, que agregam conhecimento de causa e todas as tecnologias necessárias para o processo, bem como o talento requerido para as adaptações culturais, transcriações ${ }^{4}$ e dublagens que o processo exige. Os trabalhos de localização de videogames são disputados, os profissionais realmente gabaritados são poucos, e a hora traduzida é das mais bem pagas em todo o espectro do mercado de tradução, interpretação e correlatos.

No decorrer deste ensaio discutiremos o início desse processo, em um contexto histórico bastante diferente do atual; poderemos notar uma série de condicionantes e fatores que ainda podemos observar nos nossos processos atuais de localização. Veremos que essa vinculação e confusão entre a indústria dos videogames e sua sombra - a indústria de localização - é um fenômeno que remonta à origem de ambos os segmentos em terras brasileiras.

\footnotetext{
${ }^{4}$ Os processos de localização se explicam nos termos da tradução poética e da poética ela mesma. Escreveu Anthony Pym: "A [Localização] torna [o produto] linguística e culturalmente apropriado, algo que se poderia nomear também "adaptação" ou "reinserção mercadológica" (o que corresponde ao lema de Ezra Pound, no campo da tradução poética: Make it New: Fá-lo novo)" < [LOCALIZATION] make [the product] linguistically and culturally appropriate", which we might otherwise term "adaptation" or perhaps "re-marketing" (on a par with Ezra Pound's dictum "Make it new" in the field of poetry translation) > (2013, s/p). No Brasil teríamos que nos referir ao concretismo e à teoria da transcriação de Haroldo de Campos, devedores de Pound nesse aspecto. "Transcreation”, por outro lado, já faz parte da terminologia técnica dos estudos da localização.
} 


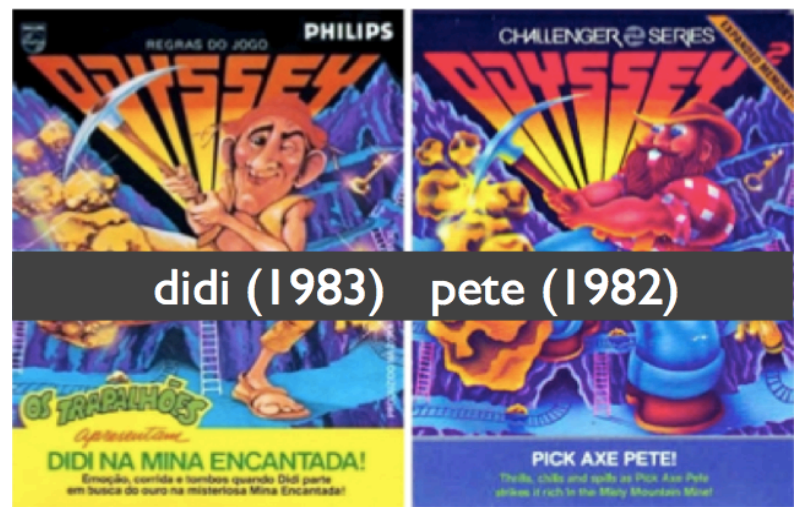

Figura 2 -

Localização pioneira:

Didi na mina encantada, a

“encarnação” brasileira de Pick Axe

Pete.

Fonte:

http://www.ostrapalhoes.net/o-psit/produtos/brinquedos/didi-na-minaencantada/

Discutiremos todas essas questões sob o ponto de vista do estudo de um caso específico em que tal (con)fusão de indústrias se mostra patente, paradigmática, assim como também estabelece o marco zero dos videogames no Brasil. Trata-se do lançamento, em 1982, de um jogo chamado Pick Axe Pete, mas que no Brasil, localizado em 1983, é conhecido como Didi na mina encantada. Para que entendamos o papel desse processo específico de localização e a relevância de sua operação cultural, é necessário que discutamos antes alguns aspectos do processo de localização de maneira geral.

\section{Não há o local do global}

Todo produto já nasce localizado. Se é lançado simultaneamente em várias praças, ou em algumas e depois em outras, ou, ainda, se em uma delas e depois nas demais é quase irrelevante: em todos os casos é o produto local que se globaliza por causa de suas localizações e não o produto global que se localiza por causa da sua globalização. Não existe o produto original internacionalizado ou extra-localizado tampouco existe uma localização ideal, fora do tempo e do espaço, desistoricizada. Não existe um local global, a partir do qual se possa produzir um bem ou um serviço. Existe entretanto uma localização central, no sentido de que ela é anterior e mais das vezes proveniente de um mercado dominante, de um polissistema mais rico, mais complexo e abrangente. Essa localização primeira só engendra um produto internacional na medida em que se diferencia em localizações posteriores, secundárias, nos mercados periféricos. A despeito da proeminência e da centralidade da localização primeira, a localização periférica se mostra duplamente relevante na sua introdução de um produto no novo mercado: é ao mesmo tempo autônoma, porque corresponde a esse mercado periférico, e, por outro lado, constituinte da dimensão internacional ou global daquele produto primeiro - aquele que permanecerá local enquanto não for localizado para outra localidade.

Localização é um tópico atualmente em evidência nos Estudos da Tradução, e um campo fértil e promissor para a pesquisa acadêmica. Não se trata de uma categoria de pesquisa ou de um conceito abstrato que tenha surgido da reflexão acadêmica, como 
admite o próprio Anthony Pym (2004). ${ }^{5}$ Longe de se ter originado na academia, o conceito de localização emergiu da própria indústria. PYM (2004, p. Xv) situa as origens do que entende ser o "paradigma da localização" nos anos 1990, com o advento da indústria de software, e na esteira das discussões acerca dos processos econômicos de internacionalização dos produtos e globalização dos processos produtivos:

Poderíamos dizer que existe um processo mais amplo, chamado "globalização", do qual fazem parte a "internacionalização" e a "localização". Para globalizar, deve-se primeiro generalizar o produto de algum modo ("internacionalização"), depois adaptar ("localizar") o produto para mercados (“locais”) específicos. (PYM, 2004, p.30 $)^{6}$

A localização se define enquanto contraponto da internacionalização, cada qual como se fosse a face oposta da outra: cara e coroa da moeda da globalização. Globalização, pois, um Jano conceitual, constituído por essa doppia faccia: por um lado a concepção de um produto internacional, apto a ser inserido no mercado global, apto para o posicionamento em quaisquer mercados disponíveis; e pelo outro lado uma concepção simultânea de adaptação do produto internacional nos locais dessa internacionalidade, ou seja, a adequação do produto à praça em que se queira posicioná-lo.

O produto internacional, assim sendo, pode também ser compreendido como o conjunto ou resultante de todas as suas variações locais - podemos até argumentar que a noção mesma de um produto internacional é meramente abstrata. Toda a configuração imaginável de um produto globalizável se encontra localizada. Nós não podemos, a rigor, comprar um produto internacional. Qualquer produto que possamos consumir é, desde já, um produto localizado. Não existe um produto originalmente internacional, uma produção ou um mercado de consumo que se estabeleça nesse inter espaço das inter-nações. Discordamos pois de Pym nesse particular. Não se trata de um produto geral ou global, que se especifica nos locais, mas de um produto local que se generaliza por força de suas localizações. O produto só se torna internacional quando localizado, quando reinserido em um outro contexto cultural, e nessa reinserção não estará nunca estabelecido que a praça original e anterior de lançamento do produto detenha uma relação de anterioridade ou originalidade frente à qual as ações posteriores de localização tenham que prestar contas.

O produto originalmente lançado em uma praça é sempre ${ }^{7}$ um produto localizado para essa mesma praça no qual foi lançado. Em termos práticos, percebemos

\footnotetext{
${ }^{5}$ Pioneiro da onda de interesse e apreciação acadêmica do fenômeno da localização, Pym vem publicando uma série de papers importantes acerca do tema, aos quais não poderemos nos referir com o devido detalhe neste ensaio. Vale conferir esses trabalhos, todos reunidos e livremente disponibilizados pelo autor em < http://usuaris.tinet.cat/apym/on-line/translation/translation.html>.

${ }^{6}$ We might say that there is one wide process called "globalization", of which "internationalization" and "localization" are parts. In order to globalize, you first make your product in some way general ("internationalization”), then you adapt ("localize”) to specific target markets ("locales”). A propósito, todas as traduções de excertos de obras estrangeiras citadas neste ensaio foram realizadas por mim.

${ }^{7}$ Referimo-nos ao mercado de bens de consumo. Ainda nesse âmbito poder-se-ia pinçar algumas exceções? Usamos as palavras “sempre” e "toda” por força retórica, e diríamos melhor "quase sempre” e "na maioria dos casos".
} 
que nos primórdios da indústria de software os aplicativos que circulavam em mercados periféricos como o brasileiro, lançados originalmente em inglês, raramente vinham localizados. O fornecedor limitava-se a traduzir os manuais, o que consiste, como sabemos, apenas em um aspecto da localização desses produtos. Tendia-se, a tomar a localização inglesa como padrão e piloto das demais, a tomar o local por global. As limitações desses processos iniciais e superficiais demonstram, todavia, que a localização eficaz está, como diria Gideon Toury (2012, p. 17-20), orientada à meta ${ }^{8}$, moldada de acordo com as restrições da praça onde o produto se está inserindo, de modo que as exigências específicas do local se sobrepõem a qualquer relação de fidelidade ou adesão para com a localização primeira ${ }^{9}$ do produto em questão.

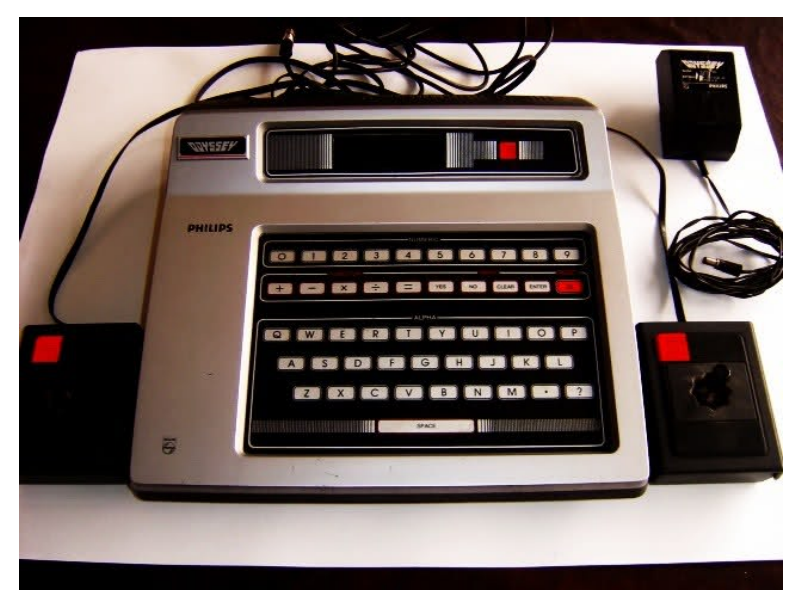

Figura 3 -

O Magnavox Odissey2 “original”

(abaixo) e a versão brasileira do console (esquerda).

A indiferenciação do produto não implica em uma internacionalidade desistoricizada, assim como sua localização primeira não se constitui, por si mesma, em um produto internacional. Fonte:

http://nowloaded.org/forum/index.php?s howtopic $=97008 \&$ st $=20$ e http://en.wikipedia.org/wiki/Magnavox_ Odyssey²\#mediaviewer/File:MagnavoxOdyssey-2-Console-Set.jpg

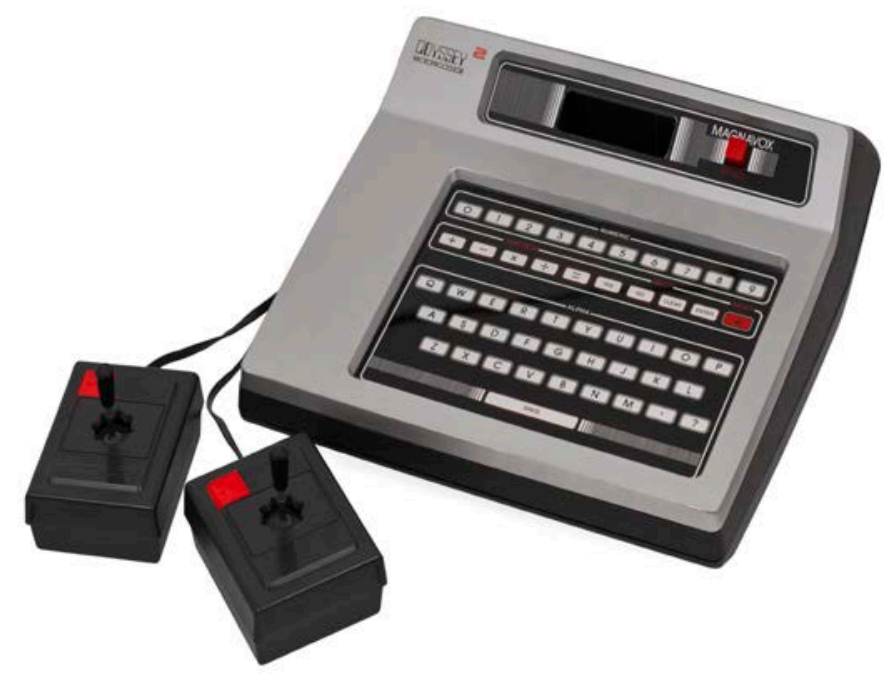

${ }^{8}$ Target Oriented.

${ }^{9}$ A localização primeira está determinada pelo local do lançamento original do produto. Todavia, do ponto de vista do produto globalizado, essa localização primeira consiste em nada mais do que uma localização dentre as demais, posteriores; primeira entre suas pares, decerto, mas tal primazia é incapaz de transcender sua localidade. 
A internacionalidade é uma função de todos os locais possíveis da localização. A localização sucessiva de um produto, por sua vez, é aquilo que expressa sua internacionalidade. Recapitulemos: a internacionalidade é uma abstração e o contexto inicial de concepção e lançamento de um produto (a sua localização primeira) não é de modo algum determinante ou dominante da configuração dos processos de localização subsequentes. Fixemo-nos nesse último ponto, pois ele será discutido quando avançarmos no estudo de nosso caso específico. Alguns outros pressupostos teóricos nos serão úteis e necessários para esse próximo passo. Um rápido "sumário crítico” das considerações de Pym (2004; 2013, passim) sobre o tema bastará para os nossos propósitos.

O idioma é a ponta-de-lança do esforço de localização exatamente porque está nele o lugar primeiro da expressão de uma cultura; a demarcação mais imediata possível de uma fronteira cultural. O nacional do local, por outro lado, se insere nessa tensão como uma modalidade do internacional. Talvez nem o próprio Pym, nem uma boa parte dos seus comentadores, tenham se apercebido disso. No caso da localização de um produto para a língua portuguesa, por exemplo: não existe uma "localização internacional lusófona”, ou um "português internacional” para o qual se localiza. Existem diversas nações que falam uma variedade do idioma português, cada uma delas constituindo um local específico. Todavia, em meus processadores de texto, tenho unicamente, entre as opções de idiomas, "Português do Brasil” e "Português" ou "Português Europeu”. A rigor, deveríamos contar também com outras variedades de português, conforme às variantes africanas, asiáticas, e assim por diante.

Persistindo nesse raciocínio, teríamos, afinal, que postular a necessidade de se localizar um produto em micro localidades cada vez mais específicas, o que quase nunca se justifica em termos econômicos. A localização, portanto, terá que apelar para essas abstrações internacionais e supra-regionais: uma localização lusófona, uma localização francófona, outra hispânica, e assim por diante. Nesse campo, a ideia de internacionalidade se mostra insuficiente e incapaz de abarcar tais fenômenos, que se mostram a um tempo maiores e menores do que a ideia de qualquer internacionalidade ou nacionalidade; apenas porque problematizam o conceito mesmo de locale. ${ }^{10} \mathrm{~A}$

\footnotetext{
${ }^{10}$ O termo “locale” faz parte da terminologia de Anthony. Pym, acerca da localização. Preservamos a forma original, ao invés de traduzir o termo por "local”, a fim de manter o sentido específico que o autor define no fragmento que citamos seguir. Nele, Pym alude também ao conceito de "distribuição", que nada mais é do que a generalidade dos processos de distribuição material de produtos e textos nas praças disponíveis, no tempo e no espaço. Passamos a citar Pym: “Os conceitos de 'língua' e ‘comunidade’ não provém critérios suficientes para distinguir os tipos de lugares envolvidos nos processos de distribuição. Daí nós termos optado pelo termo 'locale', muito mais por causa dos problemas que ele evita do que por qualquer benefício mais expressivo que nos traga. Pois bem, o que é um locale? Como definir onde um locale começa e outro termina? Suas fronteiras não são mais fáceis de traçar do que aquelas entre 'línguas' e 'comunidades'. (...) Ao invés de se procurar por essências culturais destiladas ou diferenciadas, podemos, ao contrário, procurar nas próprias localizações os indícios dessas fronteiras. (...) Isso quer dizer que, ao invés de oferecer uma definição abstrata, empregando uma terminologia traiçoeira e sem base ontológica, nós preferimos seguir as distribuições (dos produtos localizados) e permitir que elas mesmas nos revelassem onde os locales estão. O conceito de “locale”, assim, torna-se fundamentalmente empírico: os locales passam a existir apenas no momento em que se revelam por meio de sua resistência ao processo de distribuição. (...) Da perspectiva desse empirismo, os limites de um locale podem ser definidos como os pontos onde textos foram (intra ou interlingualmente) localizados. Isto é, se um texto puder ser adequadamente movido (de um lugar para outro) sem
} 
categoria francófono suscita uma configuração bastante particular nos termos de uma tensão entre centro e periferia, assim como também seria o caso de diversas outras nações agrupadas sob uma categoria eminentemente lingüística (ex: lusófono, anglófono, etc).

O resultado da localidade predominante de uma localização francófona certamente tenderá ao centro. Mas no caso de uma localização lusófona, teremos uma configuração inteiramente diversa: as forças e condicionantes dos mercados em questão sugerem que a relação entre centro e periferia dificilmente mimetizaria o ordenamento da relação histórica entre matriz e colônia. Nominalmente, uma localização lusófona, atualmente, teria que fazer muito mais concessões ao português falado no Brasil em detrimento do português europeu do que, por exemplo, uma localização francófona canadense do mesmo produto com relação a França - caso em que a potência colonial predomina sobre o mercado francófono, e determina, assim, o local da localização francófona.

localização, não haverá um novo locale. E caso um texto tenha sido localizado, ele passa a representar a distância entre, pelo menos, dois locales (...). Dessa maneira, o estudo da localização evita ter que ligar todos os pontos de contiguidade, assim como o fazem as fronteiras políticas (um locale não é um estado soberano).(...) Marketing não é geopolítica. Distribuição e localização dizem respeito a situações de contato e de troca, e não a separações lineares. Ao invés de empregar pré-concepções sobre localizações, agora nós podemos utilizar fatos sobre a distribuição, de modo a descrever contatos e diferenças entre locales." (2004: 22) [Neither "language" nor "community" provides sufficient criteria for the kinds of places involved in distribution. This is of course the main reason why we have opted for the term "locale", more because of what it avoids than for any of its more expressive benefits. What then is a locale? How might one define the points where one locale stops and another begins? The borders are admittedly no easier to draw than those between languages or communities. (...)Instead of looking for differentiated or distilled cultural essences, we can quite happily look at localizations themselves in order to see what they have to say about borders.(...) what this means is that, instead of giving an abstract definition using slippery terms with no ontological basis, we follow the distributions and allow them to reveal where the locales are. The concept of "locale" thus becomes fundamentally empirical: locales do not exist until they show themselves by resisting some process of distribution.(...) From this empirical perspective, the limits of a locale can be defined as the points where texts have been (intralingually or inter-lingually) localized, That is, if a text can adequately be moved without localization, there is no new locale. And if a text has been localized, it represents distance between at least two locales (....). In this way, the study of localization avoids having to link up all points of contiguity in the way that political frontiers do (a locale is not a sovereign state). (...) Marketing is not geopolitics. Distribution and Localization concern situations of contact and exchange, not lineal separations. Instead of using preconceptions about localizations, we can now use facts about distribution in order to describe contacts and differences between locales.] 


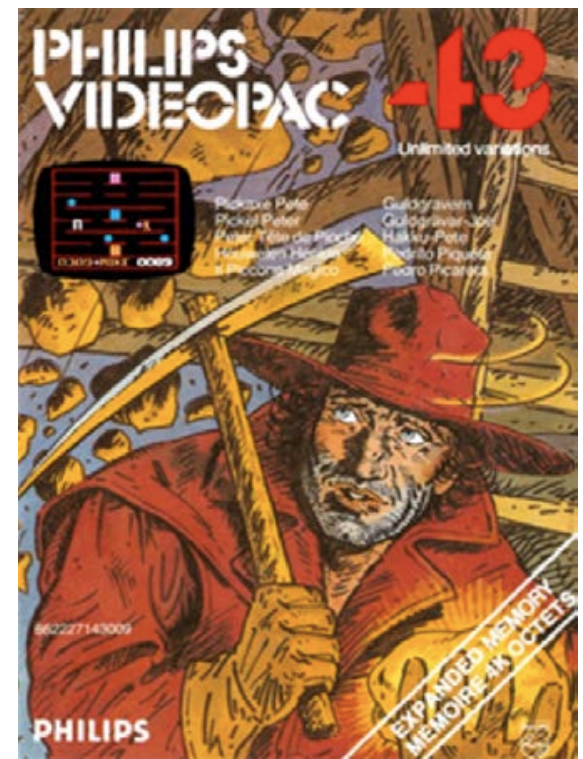

Figura 4 -

Localização europeia:

Pick Axe Pete, em compilação de jogos do Odissey para o mercado europeu. Em sua versão original, o herói do jogo, esse 'Pedro picareta', é retratado como um garimpeiro da corrida do ouro americana, um personagem de faroeste. Note-se no canto superior esquerdo uma imagem do jogo real, seus parcos pixels em franco contraste com a arte da capa. Esse tipo de apelo à imaginação do consumidor era particularmente importante nesse alvorecer da indústria. Pete ainda se chamaria Gorudo Rasshu na localização japonesa e Pierre et la Piochel na localização franco-canadense: http://www.thenextlevel.com/odyssey2/db/game.php?gameid=35 A fonte da imagem à esquerda: http://upload.wikimedia.org/wikipedia/en/3/34/Pickax e_Pete_Coverart.png

Essas complicações ilustram nosso argumento, mas fogem ao nosso escopo. Não devemos esquecer da lição de Pym: o paradigma da localização opera sobre produtos ao invés de textos. Nesse âmbito, a localização é o conjunto de tarefas de ajuste, preparo, adequação ou adaptação de um produto para uma nova situação. Todavia, essa nova situação se expressa mediada pela linguagem, por idiomas, e está sujeita às complexidades que acabamos de discutir. Ademais, tal mediação é, para além de linguística, semiológica e iconográfica. Isto é: a nova situação não demanda apenas adequação linguística - se fosse o caso diríamos tradução, simplesmente. O processo de localização de um produto não se limita ao texto e paratexto associado a esse produto, mas deve incluir também sua iconografia, sua interface para com o usuário, e intervir sobre toda a sorte de símbolos linguísticos e não-linguísticos operados em uma dada cultura.

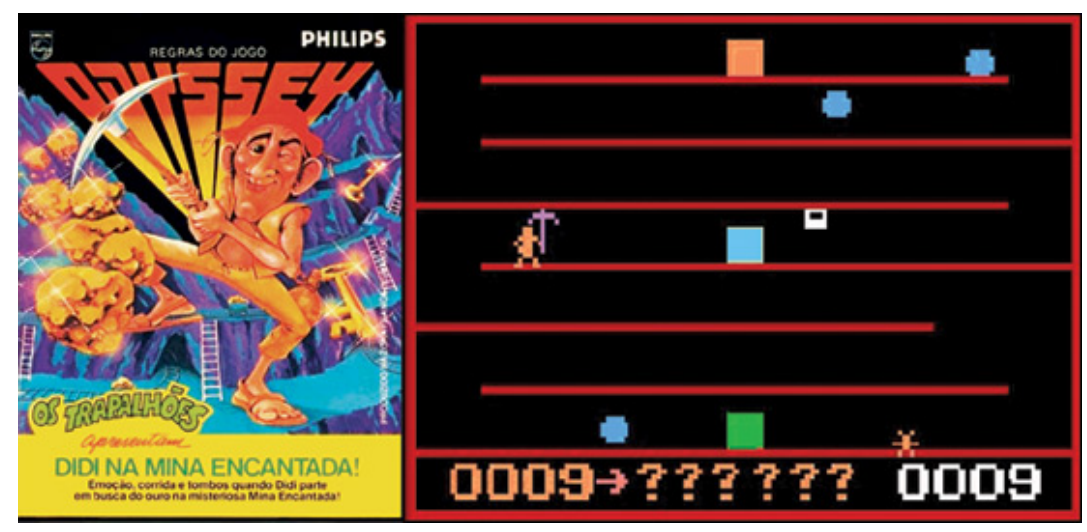

Figura 5 -

A versão brasileira da arte de capa do mesmo jogo. Pete vira Didi, mas sua configuração permanece intocada. $\mathrm{O}$ mesmo pixel.

Fonte:

http://www.gamesfoda.n et/2012/02/os-jogosbrasileiros-da-era-deouro-da-tectoy/ 
As tarefas da localização são multidisciplinares ${ }^{11}$, pois demandam uma série de habilidades e competências para a sua consecução. Nosso interesse aqui, na localização de videogames, expressa muito bem a medida em que a textualidade que permeia os processo de localização diz respeito à dimensão semiótica, ao conceito semiológico de texto; daí que as habilidades necessárias para operar a localização podem envolver profissionais de letras, artistas gráficos, dubladores, editores, músicos, programadores, entre outros.

Um último ponto que gostaria de destacar, e que recorre em Pym (2004, p. 51; 56; 67; 102; 113; 117; 128; 139; 163; 183): a localização estará particularmente sujeita a restrições. $\mathrm{O}$ postulado se fundamenta na tensão natural, que discutimos, entre o produto internacionalmente concebido e o posicionamento local desse produto. E será justamente nesse âmbito que poderemos apresentar, afinal, o caso em estudo, a partir do questionamento desse postulado.

E a questão que aqui está posta é a seguinte: existem casos de processos de localização irrestritos? Existem casos de posicionamentos de produto em um mercado meta onde não existam restrições significativas para a inserção local ditadas pelas próprias características do produto? Nas próximas seções discutiremos essa questão com base nos diversos pontos até agora destacados.

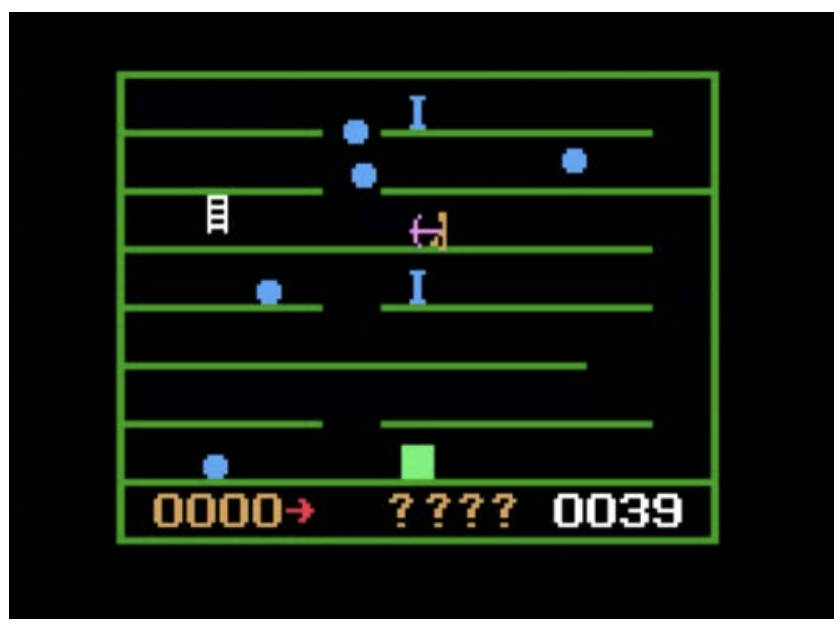

Figura 6 -

Didi ou Pete? Na era do pixel não fazia muita diferença: apenas analisando o para-texto (e.g., a capa, o manual e o cartucho que contém a ROM do jogo) se poderia dizer se o boneco representava Didi, Pete, Pierre ou Gorudu Rasshu.

Fonte: Screenshot.

(Todas as fotografias de tela foram obtidas a partir do vídeo de uma partida de Didi/Pete, capturada em um Apple Macbook rodando o emulador O2Em. Ver Referências.)

\footnotetext{
${ }^{11}$ Um projeto de localização pode mobilizar tantas tarefas, habilidades e competências quanto sua natureza o exija. O menos complexo dos projetos de localização de software demandará competências linguísticas e conhecimentos específicos da área atendida pelo aplicativo somente para dar conta dos aspectos ligados à tradução. Além disso, haverá a necessidade de habilidades ligadas à engenharia de software para implementar as modificações linguísticas e culturais necessárias. Tais habilidades poderão abranger tarefas muito diversas, que exigem profissionais diferentes: haverá quem lide com o código fonte do programa, quem faça intervenções na interface com o usuário, e quem intervenha sobre os bancos de dados vinculados ao aplicativo. Ademais, haverá a necessidade de um outro grupo de profissionais para tratar das questões paratextuais que envolvem o software e outro para implementar um eventual serviço de suporte ao usuário. Isso tudo em um projeto de pouca complexidade!
} 


\section{4-1984: Estado de exceção, reserva de mercado, política nacional de informática \& o Serviço Nacional de Informação}

Aprendemos com Even-Zohar (1990, p. 9-27) a compreender (poli)sistemas literários nos termos de posições assumidas pelos elementos que constituem os sistemas que se conectam segundo a tensão fundamental entre centro(s) e periferia(s). Esses conceitos nos parecem mais úteis no mapeamento da ascensão do paradigma de localização do que nos seriam os ambíguos conceitos de internacionalização e globalização que vínhamos debatendo.

Tenderíamos a principiar pela consideração da relação centro/matriz ao nos debruçarmos sobre um produto inserido/localizado num locale periférico. Essa consideração, entretanto, nos seria enganosa: nosso foco aqui, enquanto narradores de um processo de localização privilegiado, terá que partir da periferia, visto que estudamos o processo de localização do ponto de vista do produto localizado. Além disso, esse processo de localização, que associamos e qualificamos como periférico, é, como vimos, sempre determinante de qualquer produto tido como internacional.

Isso transparece no lançamento da plataforma de videogames ${ }^{12}$ Odissey2 no Brasil em 1983. O caráter periférico do mercado brasileiro já se pronunciava no nome da plataforma: o console perdendo aqui o "2" da nomenclatura original, procedimento que se seguia naturalmente do fato de que o Magnavox Odyssey, o primeiro console doméstico de videogame, introduzido nos EUA em 1972, jamais tenha sido produzido no Brasil. Em 1972, inclusive, a posse de um desses dispositivos em solo brasileiro poderia implicar no imediato enquadramento desse hipotético gamer pioneiro nas draconianas leis de segurança nacional.

Lembramos que esse período, de especial florescimento no campo dos microcomputadores, foi também marcado no Brasil pela segunda metade do ciclo do longo regime militar deflagrado pelo golpe de 1964. Desnecessário que se diga que os governos militares não viam com bons olhos a disseminação da tecnologia da informação, e mantinham um olhar severo e atento sobre até mesmo as instâncias mais inocentes da indústria da informática, em que se poderiam enquadrar os videogames.

\footnotetext{
${ }^{12}$ Usaremos os termos "plataforma” e "console" intercambiavelmente para referir as unidades de hardware dos produtos. Atari 2600, Intellivision, Odissey e Colecovision foram os principais consoles lançados na primeira metade dos anos 1980, e cada qual constituía uma plataforma para a comercialização dos jogos, vendidos separadamente em cartuchos que continham uma ROM (Read Only Memory). Essa ROM continha o código-fonte, i.e., as instruções binárias do jogo.
} 


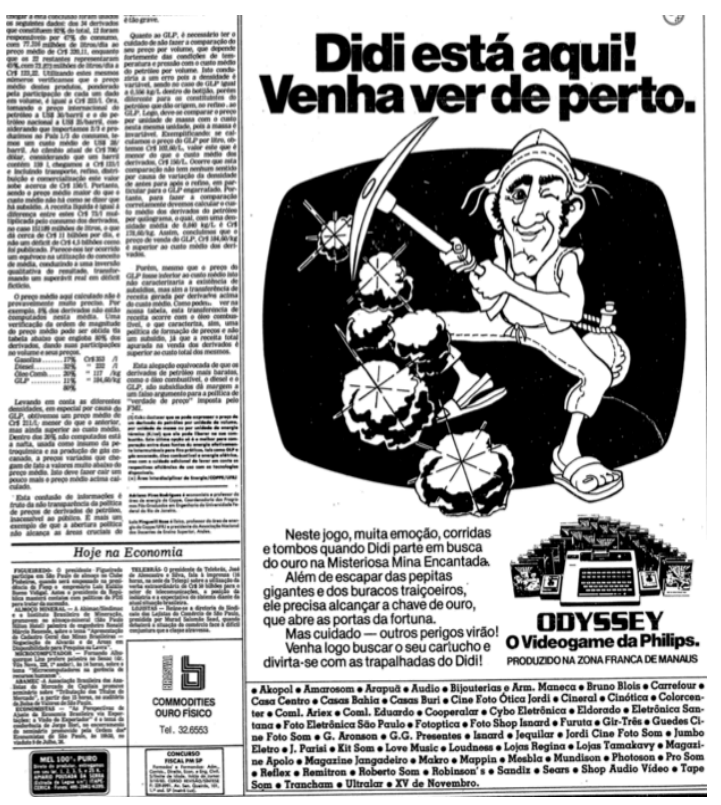

Figura 7 -

DIDI está aqui!

Venha ver de perto.

Note-se, no canto inferior

direito: "Produzido na Zona

Franca de Manaus".

A nacionalização da produção

de produtos informatizados era

obri-gatória nos "anos de

chumbo".

Fonte: Folha de São Paulo. 29

set. 1983. Caderno de

Economia, Anúncio

Publicitário, p.21

Em 1985, durante o segundo ano de vendas do Odyssey no Brasil, deu-se também a eleição do primeiro presidente civil em trinta anos, pela via indireta de um congresso eleitoral, a despeito do movimento de massa por eleições diretas que mobilizara a sociedade brasileira no ano anterior. Se aqueles entusiastas dessa nova tecnologia de entretenimento digital aguardavam sinais de uma abertura tecnológica similar àquela abertura política que se queria vislumbrar à época, é quase com tristeza que podemos sugerir que tiveram eles exatamente aquilo que queriam. A abertura tecnológica foi tão recalcitrante, lenta, hesitante e comprometida com o antigo regime quanto a abertura política!

Mais significante: em sincronia à introdução do Odyssey no Brasil, foi promulgada em 29 de outubro de 1984 a Lei 7.232, que consolidava a Política Nacional de Informática (PNI). A promulgação da lei antecedeu em poucos meses às eleições indiretas de quinze de janeiro de 1985, tratando-se, portanto, de um dos últimos atos desse último presidente militar, o general João Batista Figueiredo. No texto da lei, destacavam-se as doutrinas do controle da informação pelo estado e da proteção da indústria nacional de informática. A declaração inicial dos princípios da lei não deixam nenhuma dúvida quanto a isso:

I - ação governamental na orientação, coordenação e estímulo das atividades de informática;

II - participação do Estado nos setores produtivos de forma supletiva, quando ditada pelo interesse nacional, e nos casos em que a iniciativa privada nacional não tiver condições de atuar ou por eles não se interessar;

III - intervenção do Estado de modo a assegurar equilibrada proteção à produção nacional de determinadas classes e espécies de bens e serviços bem assim crescente capacitação tecnológica;

IV - proibição à criação de situações monopolísticas, de direito ou de fato;

$\mathrm{V}$ - ajuste continuado do processo de informatização às peculiaridades da sociedade brasileira; 


\begin{abstract}
VI - orientação de cunho político das atividades de informática, que leve em conta a necessidade de preservar e aprimorar a identidade cultural do País, a natureza estratégica da informática e a influência desta no esforço desenvolvi- do pela Nação, para alcançar melhores estágios de bem-estar social;

VII - direcionamento de todo o esforço nacional no setor, visando ao atendimento dos programas prioritários do desenvolvimento econômico e social e ao fortalecimento do Poder Nacional, em seus diversos campos de expressão;

VIII - estabelecimento de mecanismos e instrumentos legais e técnicos para a proteção do sigilo dos dados armazenados, processados e veiculados, do interesse da privacidade e de segurança das pessoas físicas e jurídicas, priva- das e públicas;

IX - estabelecimento de mecanismos e instrumentos para assegurar a todo cidadão o direito ao acesso e à retificação de informações sobre ele existentes em bases de dados públicas ou privadas;

$\mathrm{X}$ - estabelecimento de mecanismos e instrumentos para assegurar o equilíbrio entre os ganhos de produtividade e os níveis de emprego na automação dos processos produtivos;

XI - fomento e proteção governamentais dirigidos ao desenvolvimento de tecnologia nacional e ao fortalecimento econômico-financeiro e comercial da empresa nacional, bem como estímulo à redução de custos dos produtos e serviços, assegurando-lhes maior competitividade internacional.
\end{abstract}

A orientação dessa política de informática, como designam os trechos destacados, está marcada, antes de tudo, pela ação centralizadora do estado enquanto árbitro do inteiro setor. Isso se manifesta no intervencionismo estatal estabelecido pelos termos da lei, o que tem como contrapartida um evidente caráter protecionista para com a (incipiente e obsoleta) indústria nacional. Subjaz a tudo isso a herança dos anos de chumbo: a paranoica e obsessiva necessidade de que tem todo estado policial de controlar e centralizar a informação, de restringir e orientar o seu fluxo. A política nacional de informática, legada pelo último general-presidente em um de seus últimos atos oficiais, parece ter sido formulada pelos arapongas do Serviço Nacional de Informações (SNI), nas horas vagas de seus grampos telefônicos.

No que se refere à supostamente protegida e fomentada indústria brasileira de "informática” (um termo já datado), essa indústria cambaleante - sem possuir a capacidade de inovação técnica requerida para se manter competitiva frente à revolução dos microcomputadores - apoiou-se no protecionismo da PNI, que lhe proporcionara uma reserva de mercado. O resultado disso foi aquele panorama de oficialização da pirataria tecnológica, operada por uma indústria brasileira que, nos piores casos, revendia máquinas obsoletas projetadas por engenharia reversa. Temos uma extrapolação desse panorama com o caso do Unitron Mac 512 (1985), em que uma extraordinária proeza técnica por parte dos engenheiros que clonaram o então recentemente lançado Apple MacIntosh (1984) se torna representativa de um estado de coisas lastimável, quando um produto inovador não podia ser legalmente importado, nem localmente comercializado por força das severas restrições ao licenciamento e à participação de empresas e produtos estrangeiros no mercado nacional. Esse panorama se perpetuaria pelos próximos oito anos, até que os dispositivos protecionistas fossem afinal revogados pela Lei 8248 de 1991. A lei vinha na esteira de uma súbita e traumática abertura econômica, a qual se mostraria, afinal, tão desastrosa para a indústria doméstica de informática e eletrônicos como para a indústria brasileira de modo geral. 


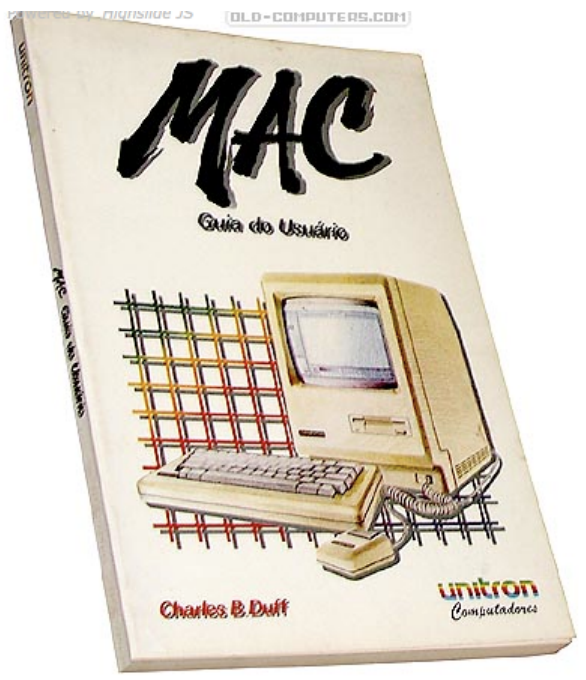

Figura 8 -

Localização por engenharia reversa.

O manual do legendário clone brasileiro do Macintosh.

A Apple acabou por impedir a

comercialização do Unitron, mas os

demais microcomputadores

comercializados na época eram clones de micros como o Sinclair e o Apple II.

Fonte: http://www.old-

computers.com/museum/photos.asp? $\mathrm{t}=1$

$\& \mathrm{c}=997 \& \mathrm{st}=1 \$$

No setor de videogames, o ambiente se fazia mais permissivo para licenciamentos. A crise dos consoles domésticos se resolve no célebre crash de $1983^{13}$ (Kent, 2001, p. 220-240), quando a primeira geração de consoles foi inviabilizada pela ascensão dos microcomputadores. Nesse ponto, o mercado brasileiro - como os demais mercados periféricos - se mostrava, afinal, interessante. Isolado pela PNI, os microcomputadores, caríssimos, ficavam além das possibilidades de compra do consumidor comum. Dessa maneira, o Brasil - que vendia microcomputadores obsoletos a preços proibitivos, e que, portanto, não poderiam concorrer na mesma faixa de preço com os consoles - seria uma praça ideal para comercializar os estoques de

\footnotetext{
${ }^{13}$ A crise de 1983 no mercado de consoles de videogames representou uma mudança de direção na indústria. Na época chegou-se a aventar a possibilidade de que o mercado doméstico de consoles havia chegado ao fim. Posteriormente verificamos que essa visão era incorreta, e que a crise de 1983 apenas revelava aquela faceta da indústria que já discutimos, e que se refere a um ciclo de vida curto devido à obsolescência acelerada do hardware. Em 1983, contudo, a indústria estava na sua infância, e a crise foi completamente inesperada. O crash se caracterizou por uma queda acentuada e contínua nas vendas de consoles e cartuchos dos sistemas que competiam no mercado. A crise decretou o fim de todas as plataformas dessa primeira geração de consoles: Intellivision, Colecovision, o nosso Odyssey2, mas, principalmente, marcou a espetacular derrocada da Atari, gigante do setor e protagonista do mercado de videogames. Dentre as causas da crise de 1983 podemos citar a ascensão da indústria de microcomputadores pessoais, a pulverização do mercado de software, e o excesso de títulos, de games inexpressivos. Do ponto de vista da queda irreversível da Atari - inesperada até porque na época a empresa pertencia ao conglomerado Warner - costuma-se elencar uma sucessão de fracassos emblemáticos da crise. Os grandes fracassos da Atari incluem o malfadado sucessor do Atari 2600, o inexpressivo Atari 5200 e seu péssimo joystick; a decepcionante implementação do jogo Pac Man, cujas vendas foram muito aquém do esperado; e, grande vilão da história, o desastroso licenciamento do protagonista do blockbuster de 1982, E.T. o extra terrestre, que foi traduzido em um jogo que costuma figurar nas listas de piores de todos os tempos, o que gerou um excedente de devoluções sem igual na indústria. As toneladas de cartuchos de E.T. enterradas e incineradas na época correspondem a um prejuízo de milhões de dólares. O mercado de consoles viria a se recuperar, mas nenhuma das companhias vitimadas pelo crash, incluindo a Atari, jamais voltaria a ocupar um lugar de destaque no mercado de consoles domésticos.
} 
cartuchos de videogames encalhados noutros mercados, aproveitando-se das bases instaladas pelos clones do Atari 2600 vendidos em território nacional ${ }^{14}$.

No caso da introdução do Odyssey no Brasil, em 1983, todavia, a indústria nacional de videogames inexistia em termos “oficiais”. O Odyssey2 original, lançado nos EUA e na Europa em 1978, era de fato um hardware obsoleto, mas o seu lançamento em terras brasileiras foi, indiscutivelmente, marcado pelo pioneirismo. $\mathrm{O}$ console, afinal, era licenciado por uma empresa que estava, a despeito de sua matriz holandesa, firmemente estabelecida em território nacional. O contexto, portanto, se mostrava favorável ao lançamento desse produto - obsoleto -, mas exigia algum esforço de promoção para viabiliza-lo no mercado brasileiro, que ainda não tivera uma exposição massiva ao mercado de videogames.

Figura 9 -

Trecho da revista Jogos 80, com foto da linha de produção da

Philips, na Zona

Franca de Manaus.

Nos tempos da reserva de mercado, a manufatura de produtos eletrônicos, por força de lei, deveria ser nacionalizada.

Fonte: Jogos 80, n. 12, p. 48-53, Dezembro de 2013.

http://www.jogos80.co m.br/edicoes/

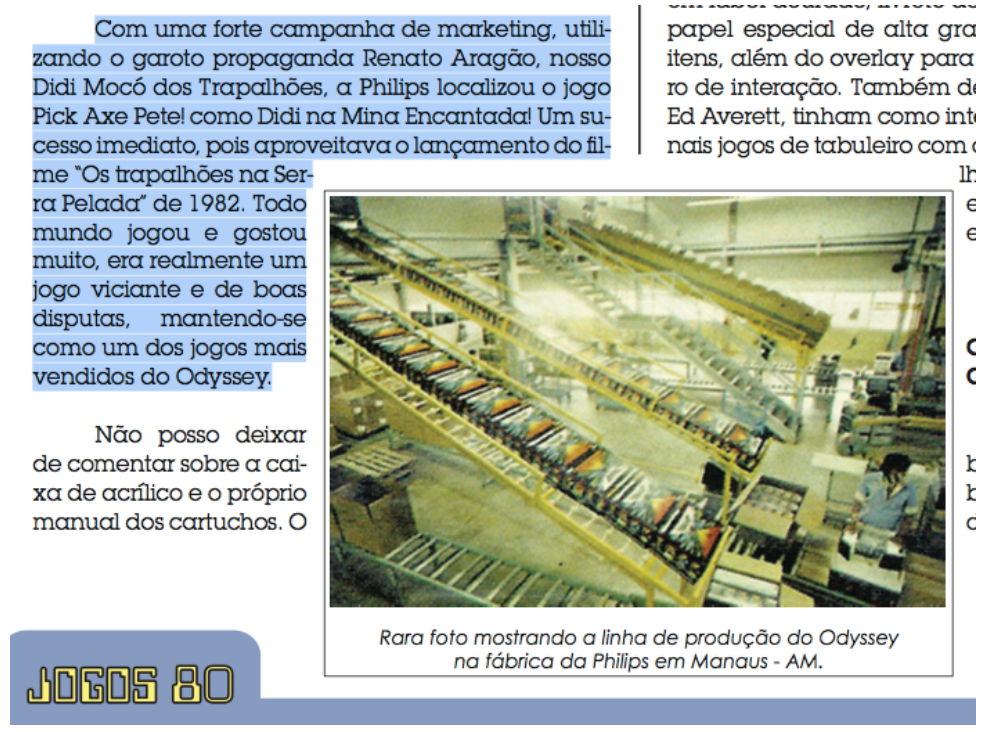

\footnotetext{
${ }^{14}$ Segundo o pesquisador Marcos Vinicius Chiado (2013, p. 04), conforme as pesquisas de mercado efetuadas pelo grupo Gradiente, e publicadas pela revista Veja e pelo jornal Folha de São Paulo, já haviam cerca de 80 mil consoles Atari, importados ao Brasil em 1983. Estes números eram bastante expressivos, e a entrada desses consoles em solo brasileiro só pode ser explicada por graus diversos de contrabando, incluindo "os dois lotes" que "de alguma forma" a Mesbla conseguiu importar nesse período (2013, p. 05). Em 1980 foram lançados os primeiro clones do Atari 2600, do empresário Joseph Maghrabi pela Atari Eletrônica, em uma flagrante pilhagem da marca e das propriedades intelectuais da empresa americana, para distribuição exclusiva no Magazine Mappin (CHIADO: 2013, p.05; 2011, p. 26). A saga dos clones nacionais do Atari 2600 começa, portanto, quatro anos antes do lançamento oficial da plataforma no Brasil, e merece um artigo à parte. Por hora terei que reportar o leitor aos livros de Marcelo Vinicius Garret Chiado, bem como aos artigos publicados na revista Jogos 80. Todas as edições da revista Jogos 80, encontram-se disponíveis para download em http://www.jogos80.com.br/edicoes/ e são de consulta obrigatória para pesquisadores e entusiastas. Todas as edições trazem entrevistas com pioneiros e atores desse período inicial dos videogames, inclusive com protagonistas da "guerra dos clones”, como o citado Joseph Maghrabi.
} 


\section{Didi Mocó Sonrisal Colesterol Novalgino Mufumbo}

Tendo nacionalizado sua linha de produção e se adequado aos ditames da PNI, a Philips se preparava para o projetado boom dos videogames no Brasil. Apostava menos no pioneirismo do que em uma agressiva campanha de marketing. Apostava também no esmero na qualidade do console e das ROMS:

Quanto aos cartuchos, interessante destacar que o projeto dos mesmos no Brasil foi algo inovador. A fim de preparar um produto mais atraente para o nosso mercado, a Philips se utilizou do modelo de manual de instrução Americano, impresso em cores e em papel brilhante, ao passo que adotou o modelo europeu de caixa, isto é a embalagem acrílica. Os jogos eram vendidos em caixa acrílica mas com manual colorido; 'o melhor de dois mundos’ por assim dizer (CHIADO, 2011, p. 68)

Figura 10 O melhor de dois mundos: As fotos não fazem justiça ao esmero da Philips Brasil na localização do Odyssey, com seu paratexto luxuoso e caixa de acrílico. As fotos foram obtidas em anúncios do site Mercado Livre.
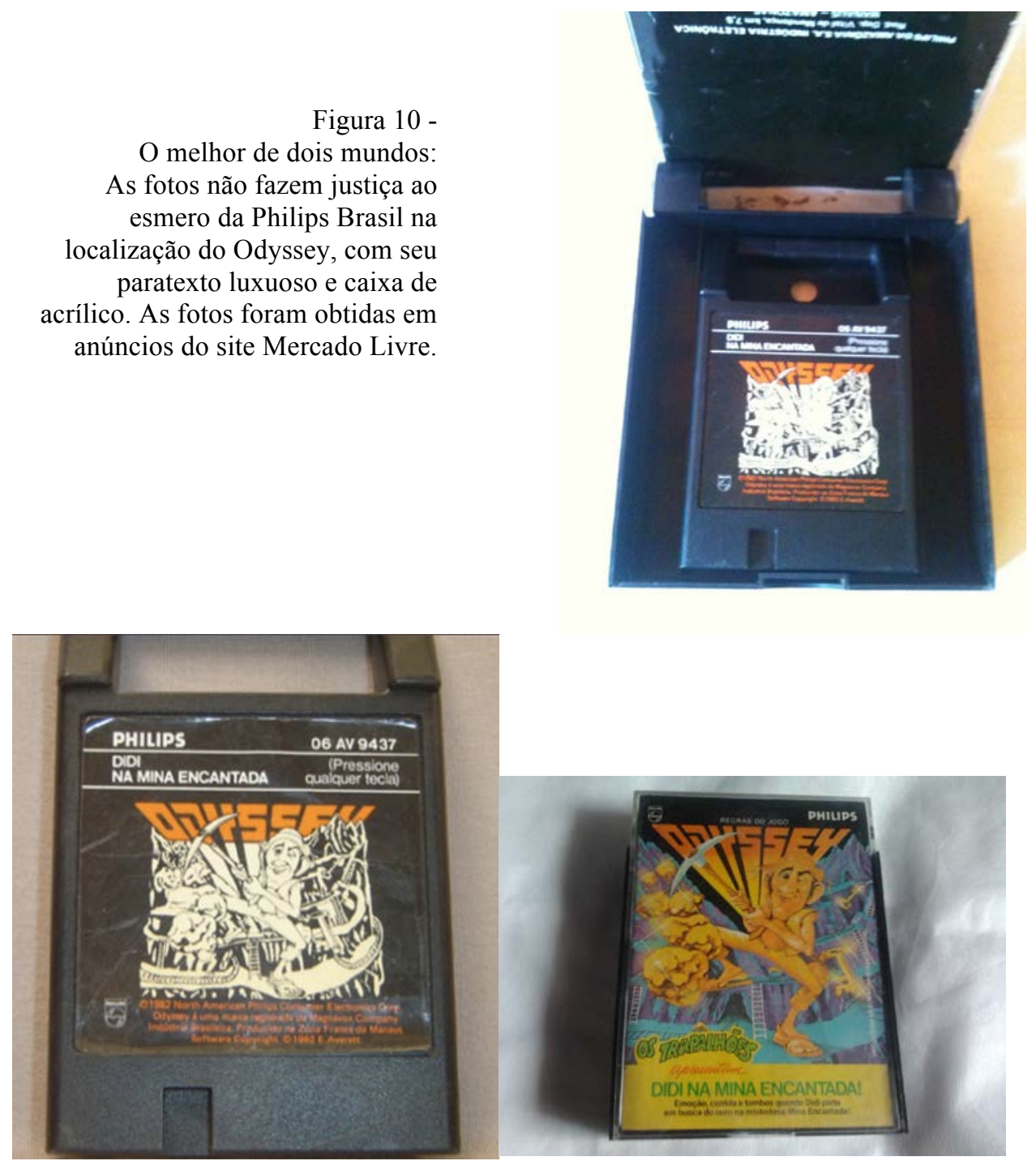
O conceito de localização permeia tal ênfase na apresentação e promoção dos produtos. Ademais, verificamos aqui um caso prático daquilo que havíamos antes discutido de maneira geral. A superioridade dos cartuchos elaborados pela Philips Brasil, e sua inteligente síntese das principais qualidades das localizações anteriores, como veremos a seguir, corrobora aquilo que dissemos sobre a inexistência de um privilégio do produto original internacionalizado, que nada mais é do que a localização primeira de um produto que só virá a ser internacional ou global na medida em que (re)localizado. No princípio era o original: o Magnavox Odyssey2 norte americano, cujo software era acompanhado de esmerado paratexto envolto em um indigno invólucro de papelão barato. Depois veio o Philips G7000 europeu; mesmo console, nome diferente - seus cartuchos distribuídos em belas e resistentes caixas acrílicas, mas os manuais vinham impressos em papel ordinário. Quando o produto aporta enfim em terras brasileiras, cinco anos depois, pelas mãos da multinacional europeia, o console volta a se chamar Odyssey, e a mera recusa em seguir o anódino nome europeu (G7000) já demonstra alguma dose de bom senso por parte da Philips Brasil. Bom senso e senso de localização, pois o software brasileiro foi distribuído com o esmerado paratexto da localização primeira da Magnavox americana, envolto pelas indestrutíveis caixas de acrílico introduzidas na localização segunda da Phillips Holandesa.

Parece que a versão brasileira inverte a hierarquia esperada na sucessão de versões: seria de se esperar que a versão nacional antes juntasse as caixas de papelão dos americanos com os manuais ordinários dos europeus, fazendo com que o software do Odyssey brasileiro viesse distribuído com a absoluta falta de capricho que seria de se esperar de um produto que, claramente, estava no final do seu ciclo, e, além do mais, sendo lançado em um mercado periférico. A Philips brasileira - provavelmente atenta ao lançamento iminente do Atari 2600, licenciado pela Gradiente - resolveu fazer o contrário, desafiando o complexo de vira-lata que assola nosso varejo de diversões eletrônicas. A filial superou a matriz nesse aspecto, e nem por isso deixou de enviar seus dividendos para a Holanda, não deixou de pagar os seus roaylties.

O paradigma da localização atua sob produtos ao invés de textos. A Philips sabia que tinha em mãos um produto inferior ao seu concorrente direto, justamente porque sua biblioteca de software era indiscutivelmente menos abrangente. Fabricados por inúmeras empresas, os cartuchos compatíveis com o Atari 2600 disponibilizavam centenas de jogos, contra as poucas dezenas de jogos para o Odyssey exclusivamente contidos em cartuchos fabricados pela Philips. Uma saída era apelar para algumas características distintivas do próprio console (que prometia muito, mas cumpriu muito pouco em termos de acessórios e funções futuras). Outra saída foi, justamente, o esmero na localização dos poucos (mas bons) jogos disponíveis. O melhor dos mundos seria a síntese das localizações americana e europeia

Todos os jogos do Odyssey brasileiro, nesse período inicial a que nos referimos, foram distribuídos com o esmero que descrevemos. Por outro lado, diversos fabricantes brasileiros, a partir de 1979, se aproveitaram das flexibilidades da legislação brasileira da época - em termos de se ignorar patentes e propriedades intelectuais -, e lançaram consoles e jogos compatíveis com o Atari 2600. Esses jogos frequentemente tinham manuais traduzidos ou adaptados para o português, e quase sempre recebiam nomes brasileiros - inclusive eram hackeados de modo a exibir o nome do fabricantes local, não-licenciado, amparado pela lei brasileira, pela PNI, como 
um pirata do rei, impondo-se ao fabricante original, negando-lhe o nome de fantasia (e.g.: Activision, Atari), na tela de abertura do jogo. Tudo isso é tradução, entretanto todas essas ações operam no nível do texto. O paradigma da localização não se faz aqui presente - ainda.

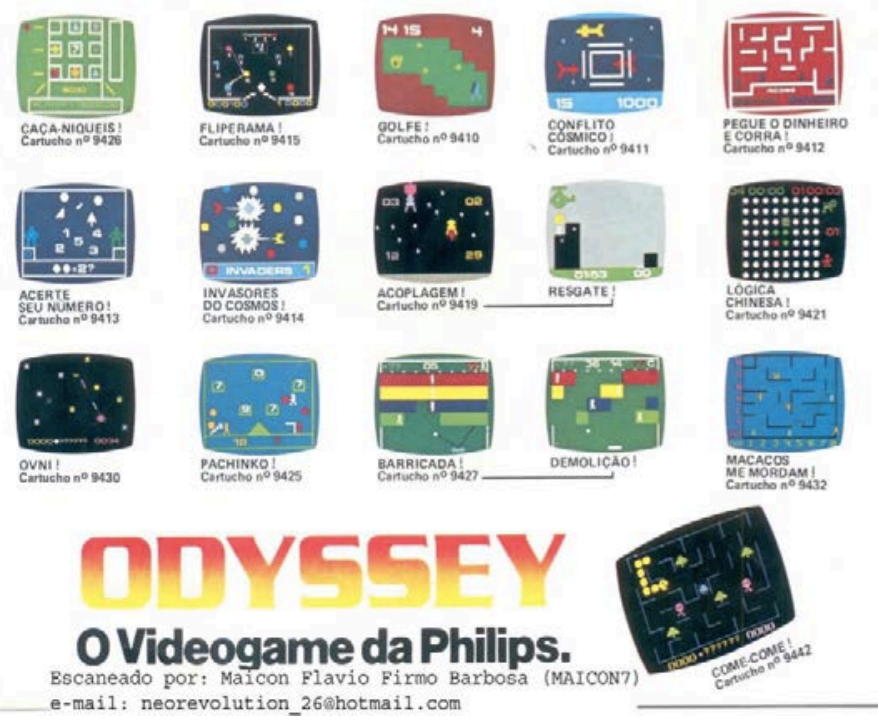

Figura 11 -

Títulosnacionalizados são apenas um aspecto do processo de localização. Fonte: Revista Odyssey Aventura, escaneada pelo MAICON7.

Eu defendo que a primazia do Philips Odyssey, no que se refere à localização de videogames no Brasil, começa com o esmero na produção de seus jogos, produto da síntese dos melhores aspectos das estratégias forasteiras anteriores de localização. O cartucho brasileiro era melhor do que os originais, se diferenciava deles, superava-os, e designava a melhor configuração do produto. A relocação brasileira consagra o Odyssey como um produto global. A Phillips Brasil, nesse particular dos cartuchos, localizou um produto, enquanto os piratas oficializados do concorrente apenas traduziam textos, e vandalizavam o software alheio.

A Philips também traduziu seus manuais e abrasileirou os nomes dos jogos. Mas não se limitou a isso: essas traduções foram apenas a faceta linguística de um esforço geral de posicionamento de um pequeno ecossistema de produtos no mercado brasileiro. Console e cartuchos adaptados, excelente acabamento, paratexto traduzido, campanhas publicitárias: é a totalidade dessas atividades, o conjunto dessas práticas, que consagra a introdução do Odyssey como o primeiro esforço de localização de um videogame em terras brasileiras. 
Figura 12 -

O sucesso do Senhor das Trevas: A Philips Brasil veiculou diversas propagandas em jornais e revistas, assim como despertou o interesse

dos cadernos de informática e entretenimento.

Fonte: Folha de São Paulo. 23 nov. 1983. Caderno de Informática p.1.

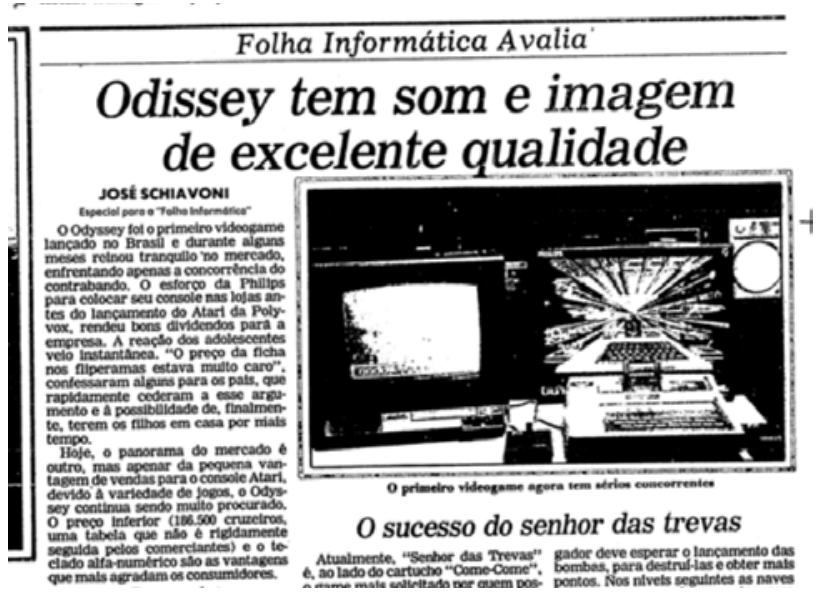

A joia da coroa desse processo, o apogeu e o momento mais significativo da odisseia do Odyssey enquanto pedra fundamental da indústria de localização de videogames no Brasil, ocorre por meio de um acordo que foi, não sem razão, qualificado como magistral:

Em julho [de 1983] custando 165 mil Cruzeiros (aprox. R\$2.075,00) o Odyssey continuava o campeão de vendas, reinando supremo e com a coleção de jogos aumentando vagarosamente. Em agosto, a Philips fez uma jogada de mestre e lançou o jogo Didi na mina encantada, valendo-se do sucesso do filme 'Os Trapalhões na Serra Pelada” juntamente com outros oito títulos. A negociação já havia começado no final de 82, tendo a ideia partido da fabricante do Odyssey, que aproveitou as semelhanças do cartucho importado 'Pick Ace Pete' ('Pedrinho Picareta', em tradução livre) cuja temática era igual à do filme. Produziram-se a embalagem e os manuais com base em arte gráfica dos Trapalhões, tudo em português. (CHIADO, 2011, p.69)

Figura 13 Capa do DVD, com o filme dos trapalhões que inspirou a principal estratégia de localização do Philips Odyssey.
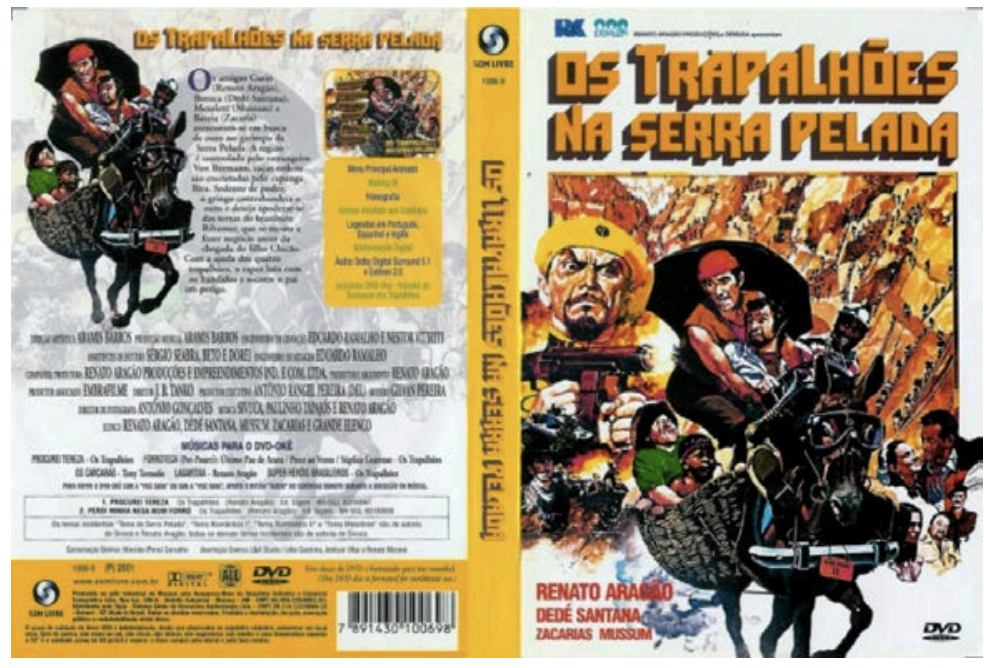
Didi Mocó Sonrisal Colesterol Novalgino Bufunfo é um personagem criado pelo humorista cearense Renato Aragão. Os Trapalhões foram/são (sem concorrência) a trupe humorística mais bem sucedida da história do Brasil. Quando o quarteto clássico (Didi, Dedé, Mussum e Zacarias) se estabeleceu nessa época, eles eram os Beatles e os Irmãos Marx da comédia brasileira, astros do disco, do cinema e da televisão, com um programa dominical campeão de audiência veiculado na TV Globo, a principal rede de televisão brasileira durante toda a década de 1980.

Ícones dos meios de comunicação de massa, absolutamente identificados com o público infanto-juvenil e, ademais, adorados pela família inteira, os adoráveis Trapalhões emprestaram exatamente o tipo de sucesso que a Philips desejava. Em verdade, os Trapalhões e o Philips Odyssey pareciam destinados a celebrar núpcias olímpicas, bodas celestiais: ambos favoreciam a venda de televisores (a Philips era uma das principais fabricantes), ambos apelavam para diversas faixas etárias num contexto familiar, ambos prometiam entretenimento familiar barato, e apelavam para o panorama de crise financeira e a ressaca do "milagre” econômico dos militares.

Esses produtos precisavam convergir numa joint venture, aliados potenciais num venturoso empreendimento de conquista de uma parca mas preciosa parcela do escasso orçamento familiar da classe média brasileira de 1983. Ademais, os Trapalhões eram um veículo: excelentes garotos-propaganda e protagonistas de um programa televisivo que permitiria inserções publicitárias durante os intervalos. Tais inserções poderiam ser potencializadas pelo posicionamento do produto nos quadros do programa - e.g. os Trapalhões apareceriam “incidentalmente” jogando o Odyssey enquanto executavam, com precisão, alguma pérola de incorreção política. Entretanto, nunca houve um jogo chamado Os Trapalhões na mina encantada. Essa trupe era composta por quatro comediantes de gênio, mas havia nela um único homem de negócios:

Renato Aragão está entusiasmado com o projeto. 'Lançado este primeiro jogo vamos testar o Mercado. Se a aceitação for boa, podemos até pensar em lançar um jogo por filme’ (a declaração é anterior à entrevista do dia 18 de agosto, na qual Didi, Dedé, Mussum e Zacarias anunciaram que não farão mais filmes juntos.) A ideia de fazer um jogo com o líder dos trapalhões adaptou-se como uma luva à criativa estratégia de marketing da Renato Aragão Produções. 'Nossos filmes, para crianças, são como brinquedos. Elas nunca querem ver uma vez só. Os videogames inspirados em nossos filmes se adaptarão perfeitamente a essa ideia' diz Paulo Aragão, gerente comercial da empresa. A fabricação dos cartuchos é feita em Manaus, como toda a linha Odyssey. (CHEGOU a jogo mania (1983) apud CHIADO, 2011, p.70) 


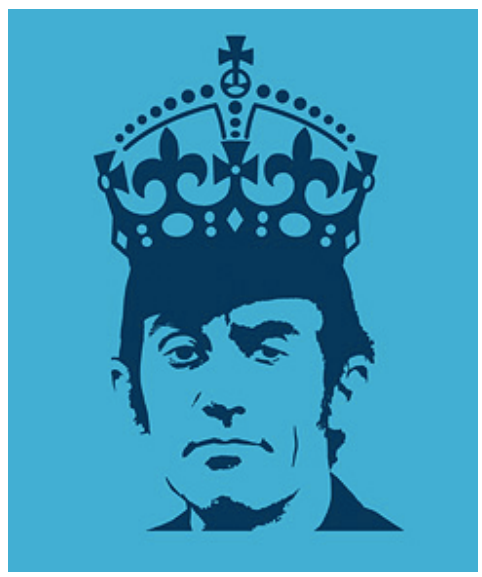
Figura 14 -
A vagabundagem benevolente do Didi Mocó, a criatura, contrasta com a diligência do criador, Renato Aragão. Onde o primeiro parecia soprado pelo vento, o segundo deixava muito pouco ao acaso. Formado em Direito, Aragão tinha muito tino para os negócios. Em 1983 a Renato Aragão Produções já era quem mais arrecadava no cinema brasileiro. Em comum com o seu alter ego trapalhão, Renato tem só a esperteza.
Fonte: http://www.nerdstore.com.br/p/camiseta-keep- calm-aguarde-e-confie.html

A separação do quarteto não haveria de durar muito, e podemos apenas especular até que ponto a cisma não terá sido motivada pelo monopólio individual, por parte de Aragão, dos contratos de licenciamento que, afinal de contas, advinham do prestígio angariado pelos esforços coletivos do grupo. $\mathrm{O}$ fato é que Aragão, ou melhor, o garimpeiro Didi Mocó, tornou-se a vedete dos esforços de localização do Odyssey.

O inverno de 1983 marcou o lançamento de uma revista intitulada Odyssey Aventura, editada pela Mauro Ivan Marketing Editorial Ltda, sob a "supervisão da Philips do Brasil”. Circulando trimestralmente, a revista era um veículo para o Odyssey brasileiro e trazia propagandas dos jogos disponíveis, breves resenhas, promoções, concursos entre jogadores e “dicas dos campeões”. O esforço de localização acenava para uma comunidade local, mas a isca para as massas era o Didi. A caricatura do trapalhão - magistralmente capturada pelos profissionais da Mauro Ivan Ltda dominava a revista (ver figura 15) e figurava nas propagandas em periódicos de circulação nacional $^{15}$. O primeiro esforço consequente de localização de um videogame no Brasil tinha um nome, uma imagem pública, uma face - e uma estrela.

\footnotetext{
${ }^{15}$ Se minha memória me serve bem, Aragão teria até estrelado uma propaganda televisiva, caracterizado como garimpeiro. Lembro de pedras rolando contra o Didi, como na sequência original de "(Indiana Jones e) Os Caçadores da Arca Perdida” (1981) https://www.youtube.com/watch?v=Pr-8AP0To4k. Infelizmente não pude localizar esse comercial, nem confirmar sua existência com outro testemunho. $\mathrm{O}$ comercial do Odyssey comprovadamente veiculado à época pode ser visto em https://www.youtube.com/watch?v=SVXSCkqUb3I . Incidentalmente, há um divertido comercial do Atari 2600 figurando o rei Pelé, o piloto Mario Andretti, e o jogador de basquete Kareem Abdul-Jabbar: https://www.youtube.com/watch?v=1GN-OmsRcbY.
} 


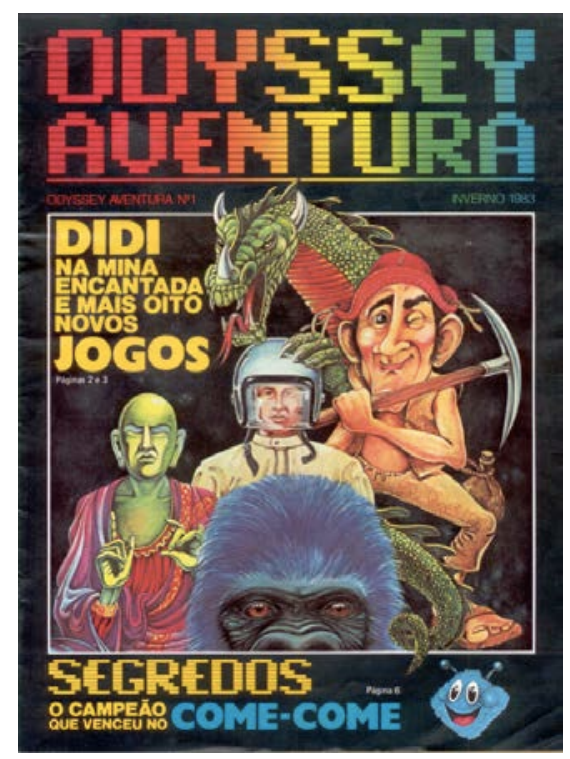

Figura 15 -

Capa do primeiro número da revista Odyssey Aventura. Com seu esmerado projeto gráfico, supervisionado pela Philips Brasil, a revista poderia ter sido uma das grandes pontas de lança do lançamento do Odyssey, mas sua circulação foi muito restrita. Mesmo assim a revista teve oito números, alguns dos quais digitalmente preservados: nossos melhores registros do apuro visual e da qualidade artística associada ao Odyssey brasileiro. Notese o destaque dado para a figura do DidiGarimpeiro, de picareta na mão, dando uma piscadela para quem quer que o esteja contemplando.

Fonte: Revista Odyssey Aventura.

Dissemos que um esforço de localização está sujeito às restrições do novo local perante as características determinadas pelos locais anteriores, aquelas localizações primeiras, originais. A era do pixel, marcada pela precariedade gráfica dos personagens expostos na tela do videogame, tornava essas restrições muito menos significativas. Não havia nada que impedisse que aquele rudimentar bonequinho, chamado Pete nas versões americana e europeia, viesse a se chamar Didi na versão brasileira. Devido às restrições tecnológicas, o personagem era uma configuração do boneco-palito que qualquer criança emprega para representar a figura humana, e poderia representar qualquer ser humano, inclusive o Didi. Na verdade, apenas a performance do boneco os seus saltos e a sua mobilidade - opera enquanto construtora da personagem no jogo - a parte mais “narratológica” da caracterização está delegada ao paratexto.

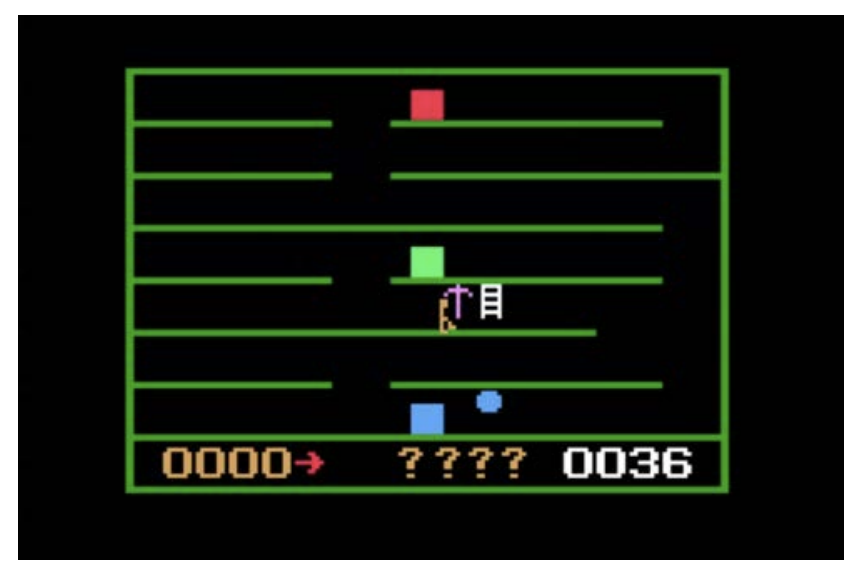

Figura 16 -

Restrição zero:

As limitações gráficas do Odyssey possibilitavam infinitas possibilidades de associações, recriações e trancriações, pelo menos no que se refere à identidade do protagonista. Note-se o motivo da escada. 
A performance nos informa o contexto do jogo e a forma pela qual seus elementos interagem. É apenas devido ao seu movimento e a sua utilização que podemos concluir que o objeto que a personagem que controlamos traz nas mãos é uma picareta, e não um guarda chuva. Os parcos pixels do jogo apenas sugerem a mina encantada, e não determinam nada quanto à identidade do bonequinho garimpeiro. A Philips Brasil bastou assinar os seus contratos com a Renato Aragão Produções e a Mauro Ivan Ltda. Tendo obtido os direitos sobre a personagem e dispondo das excelentes criações artísticas que ilustravam o paratexto e a publicidade do jogo, a Philips era dona da situação, e ninguém mais poderia dizer se aquele pixel garimpeiro chamava-se Didi ou Pete. A resenha publicada na Odyssey Aventura não deixava dúvidas quanto à natureza da operação, nem quanto ao "sonho permanente" de todas as empresas envolvidas nesse garimpo da pedra de toque da localização de games no Brasil. Que ninguém se engane, a Philips, como o Didi, estava correndo pelo ouro:

\begin{abstract}
Você conhece bem o Trapalhão e aventureiro Didi. Sua agitação e seu sonho permanente de enriquecer de repente. Entre com ele na Mina Encantada. Picareta na mão, descubra os filões de ouro e vá somando pontos. Enriquecendo com o Didi. Mas, ao descer nestas galerias profundas e desconhecidas, todo cuidado é pouco. Desmoronamentos podem pegá-lo de surpresa. Enormes pedregulhos vão rolar constantemente, ameaçando a vida do Didi quando ele estiver sem a picareta, e, consequentemente, tirando você do jogo. É preciso pular os pedregulhos, mergulhar para evitá-los quando eles vierem voando. É preciso manter-se vivo. Vivo para encontrar novos filões de ouro que os próprios pedregulhos, ao se chocarem, vão revelar. Preste bem atenção. Algumas pepitas de ouro vão cair do teto e poderão transformar-se em uma chave. E com esta chave você vai poder abrir as portas mágicas da mina. Portas que vão somar pontos para você e realizar os sonhos de riqueza do Didi. Mas tome cuidado. Algumas portas podem trazer grandes desafios para o Didi enfrentar. Entre com ele na Mina Encantada e boa sorte. (1983, p.2)
\end{abstract}

A mina de ouro dessa primeira geração dos consoles domésticos de videogame possibilitava processos de localização praticamente irrestritos, permitindo às empresas que relocavam o produto uma amplitude de manobra invejável, e que mais tarde se tornaria impossível na medida em que os pixels se multiplicavam.

Poucos anos depois, na geração seguinte de consoles de 8 bits, uma empresa brasileira se dedicou a adaptar para o Sega Master System um obscuro videogame chamado Wonderboy in Monsterland. A transformação de Wonderboy em Mônica na terra dos monstros foi muito mais problemática e custosa do que a transformação de Pete em Didi. Os gráficos mais apurados do Master System exigiram que se interviesse no código do jogo original, de modo a se substituir os personagens de Wonder Boy por personagens da turma da Mônica, dos estúdios Maurício de Souza. No caso do Didi, nada disso foi necessário. 

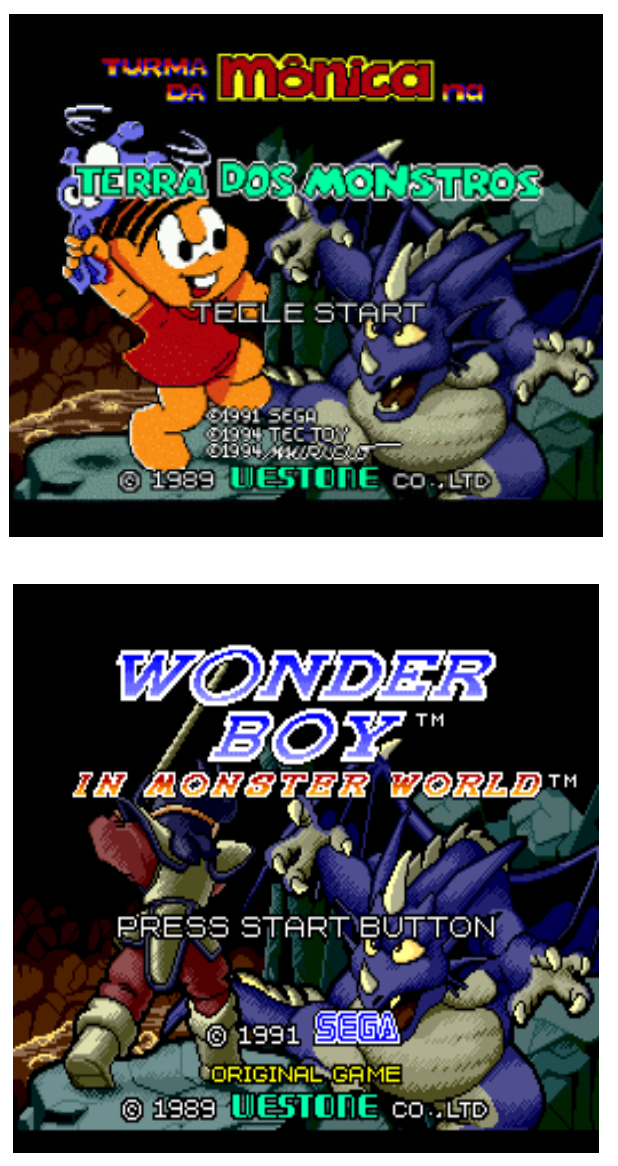

Figura 17 -

Depois da mina encantada:

Seguindo os passos da Philips Brasil, a Cia. de brinquedos Tectoy licenciou, em 1989, a Turma da Mônica, de Maurício de Souza, utilizando as personagens da empresa em substituição àquelas que figuravam no videogame Wonderboy in Monsterland. Tecnicamente, o esforço de localização foi muito mais complexo, pois a superioridade gráfica da nova plataforma (o Sega Master System) exigiu uma intervenção no código do jogo, de modo a inserir as figuras da protagonista e de sua turma - figuras reconhecidas imediatamente por três gerações de brasileiros. A sofisticação tecnológica elevou o grau de complexidade do processo de localização, mas o modelo estabelecido pela Philips em 1983 com o Didi foi claramente retomado pela Tectoy.

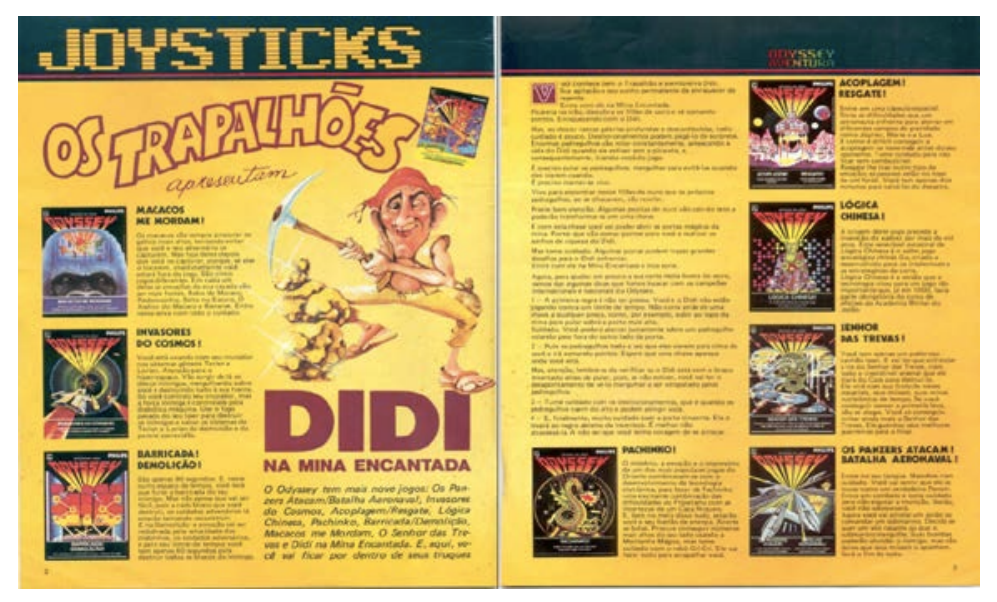

Figura 18 -

Páginas da revista Odyssey Aventura n. 1 , promovendo os jogos do Odyssey, com o habitual destaque para o Didi. 


\section{A mina que não era encantada: trapalhadas, videogames e a intervenção federal no garimpo de serra pelada}

O esforço pioneiro de localização empreendido pela Philips do Brasil foi capitaneado pela associação do personagem Didi Mocó ao videogame Pick Axe Pete. Pete foi eliminado do (esmerado) paratexto da versão brasileira. Destituído de seu reino paratextual, o avatar de Pick Axe Pete no videogame não tinha força para se impor: nada havia nele que o distinguisse como Pete, nada nele que negasse a sua infligida didi-mocosidade. Pete era, afinal, um joão-ninguém, um personagem genérico, um Sísifo que subia e descia intermitentemente as escadas de sua mina de ouro. Pete era apenas o protagonista de uma variante (muito divertida mas) semi obscura de Donkey Kong (lançado um ano antes em arcade machines) habitando uma plataforma obsoleta (o próprio Odyssey2).

Pete era, muito convenientemente, atacado pelas próprias pepitas de ouro que prospectava. Correndo, pulando, esquivando-se, picaretando, apanhando chaves e atravessando portas, mina após mina até a morte inevitável. Eliminou-se Pete, e o Didi trouxe algum carisma e encanto para essa prospecção infernal. Tínhamos, pois, um bom jogo derivativo em sua versão original, mas esse jogo não tinha um ícone à altura de sua jogabilidade. Na localização, Didi Mocó assume esse papel e preenche essa lacuna. Pete não era um personagem carismático em seus locais primeiros, não era um Mickey Mouse, um Mario ou um Donkey Kong. Didi, no Brasil, era tudo isso e muito mais. Novamente a Philips brasileira superava as matrizes, sofisticando o produto original. Apresentava uma personagem que vendia muito bem o jogo, ao invés de um jogo que mal vendia a personagem. Didi prevaleceu e nunca houve, tampouco, um jogo chamado Pedro Picareta na mina encantada para o Odyssey brasileiro.

O que tornou essa associação tão pertinente e tão admiravelmente "bem bolada”? A significância dessa operação não pode ser explicada apenas nos termos do carisma de Aragão e/ou do esmero do produto - muito menos nos termos da inexistência de restrições à substituição das personagens. Esses elementos são componentes e facilitadores do processo, mas aquilo que deixa o Didi tão confortável, tão verossímil na mina encantada - e, consequentemente, aquilo que permite tamanho sucesso na associação do jogo ao personagem - foi o sucesso do filme Os Trapalhões na Serra Pelada, de 1982.

Lançado um ano antes do próprio Odyssey, na esteira do processo de intervenção federal sobre o gigantesco garimpo de Serra Pelada no sudeste do Pará, o filme dos Trapalhões apresentava, introduzia e consagrava o Didi-garimpeiro. Com o sucesso do filme ainda fresquinho na memória do consumidor brasileiro, a associação do jogo com a personagem parecia inevitável. O que se evitou, todavia, foi o nome Serra Pelada - ao contrário de outras nacionalizações nos títulos de cartuchos do Odyssey, como Interlagos. O que se olvidou, por outro lado é que o Didi, no filme, nem sempre carrega uma picareta, como podemos verificar na figura 19. O "picareta" do grupo era Mussum, e o Didi carregava uma pá. Mesmo assim, jamais houve um Mussum na mina encantada. O acordo entre a Renato Aragão Produções e a Philips do Brasil só tinha lugar para um único trapalhão. 


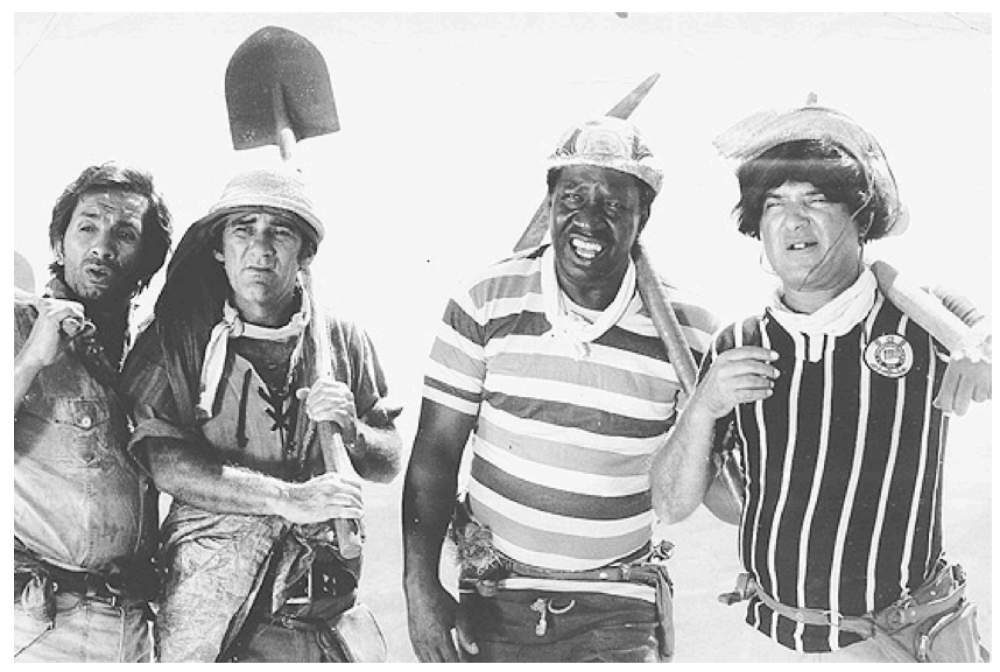

Figura 19 -

Um still da produção

do filme dos

trapalhões figurando

o quarteto completo.

Note que não é o

Didi que carregava a

picareta.

Fonte:

http://f.i.uol.com.br/f

olha/folhinha/images

/13038587.jpeg

No curtíssimo prazo, a ligação entre o filme e o videogame se mostrou uma mina de ouro. Curioso é que os ciclos de vida do garimpo em Serra Pelada e do próprio Odyssey pareçam interligados, numa sincronia espantosa que transcende a apropriação do Didi-garimpeiro. Senão vejamos: em 1976 descobre-se ouro em Serra pelada e em 1978 é lançado o Magnavox Odyssey2. Entre 1984 e 1986 tanto o garimpo quanto o videogame estão em seu auge. Em 1987 foi o fim de tudo para ambos. O garimpo esgotado, a plataforma obsoleta. Serra Pelada e o Philips Odyssey constituem-se em dois ícones da crise brasileira da década de 1980, operando em sincronia. O esgotamento súbito de todos esses filões é aquilo que costumamos qualificar como $o$ fim de uma era.

O filme, pois, define esse processo de localização. Com o filme vinha tudo de bom e de ruim que o acordo Didi/Philips poderia render. De bom vinha a apropriação do Didi-garimpeiro em busca do ouro, as imagens e recordações do filme potencializando a imaginação dos jogadores, e compensando a precariedade gráfica e o minimalismo dessa arte do pixel. E de ruim? Nada que tenha prejudicado a Philips, ou limitado as vendas de seu produto. Mas é inegável que a sombra de Serra Pelada se projetou sobre a mina encantada do Odyssey. Didi trouxe consigo o caos social do garimpo para dentro do videogame da Philips.

O filme dos Trapalhões era uma farsa nacionalista - ufanissimamente dedicada ao exército brasileiro - que glorificava a intervenção militar no garimpo em 1980. No final, o exército salva o dia, como se fosse uma cavalaria de faroeste caboclo. Os vilões de chanchada seguiam a lógica de um filme pautado pelas opiniões e valores do governo militar da PNI: eram o capataz local (interpretado por Eduardo Conde), que obedecia ao advogado inescrupuloso (Wilson Grey), que por sua vez obedecia ao principal vilão dessa farsa - o capital estrangeiro, representado por um caricato $M r$. John, a misturar inglês, alemão e português. A despeito do clima farsesco, impactava sobre a Serra Pelada fingida dos Trapalhões, sobretudo, o inescapável realismo que as imagens do filme revelaram. 
O realismo se interpunha sobre a chanchada toda vez que a miséria humana do garimpo figurava nas telas, e ela figurava a todo momento. Não poderia ser diferente, o filme - na melhor tradição neorrealista - foi rodado em locação, na própria Serra Pelada, fazendo uma caricatura de acontecimentos que estavam em curso no momento mesmo em que o filme viesse a ser exibido nos cinemas. A despeito de ser um filme dos Trapalhões, esse retrato do garimpo é - até inadvertidamente - muito mais realista do que um filme supostamente adulto - como o "Serra Pelada” de 2013 - jamais conseguiria ser.

Os Trapalhões na Serra Pelada foi rodado no meio das coisas, no local onde elas se davam, e por isso mesmo é mais interessante no século XXI como documento da corrida do ouro do que como entretenimento familiar. Aliás, quem o assistir agora, com os paramentos de hoje em dia, perceberá que dificilmente se encontraria um entretenimento menos familiar, um filme mais inadequado ao público infanto-juvenil. Basta assistir a primeira cena: uma stripper dança de biquíni, com cédulas coladas no corpo; um garimpeiro sobe no palco, com uma pepita na mão: "Hoje eu estou pagando”. Daí para a frente o filme é violento. Trata-se de uma violência crua, de capatazes e exploradores. O formigueiro humano no garimpo é onipresente e real certos fotogramas tem o mesmo impacto das célebres fotos de Sebastião Salgado em seu ensaio sobre Serra Pelada.

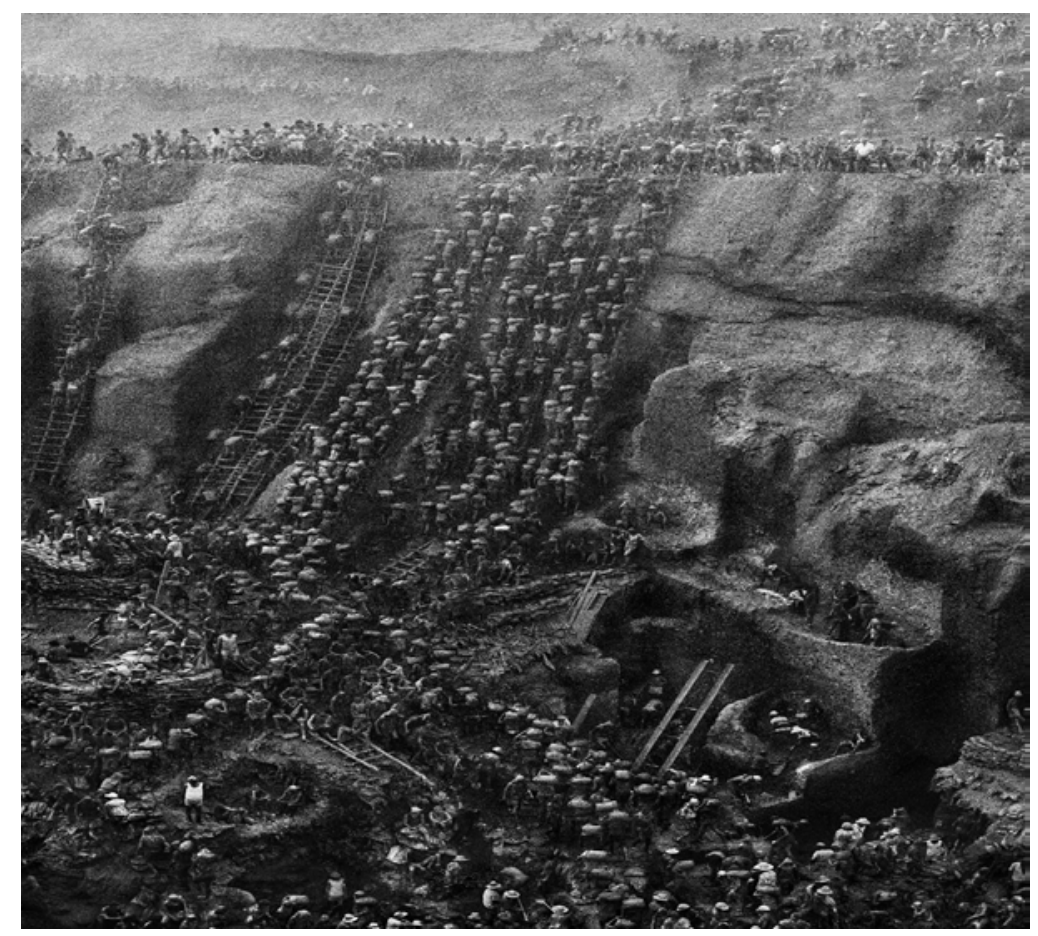

Figura 20 -

Formigueiro humano:

$\mathrm{O}$ auge do garimpo de

Serra pelada, nas lentes de Sebastião Salgado, em célebre ensaio fotográfico. Essa cava está hoje submersa por lago que se formou com a ação da chuva.

Fonte:

http://www.earthisland.or g/eijournal/winter2010/i mages/1kwordsFull/8611-46-32.jpg 

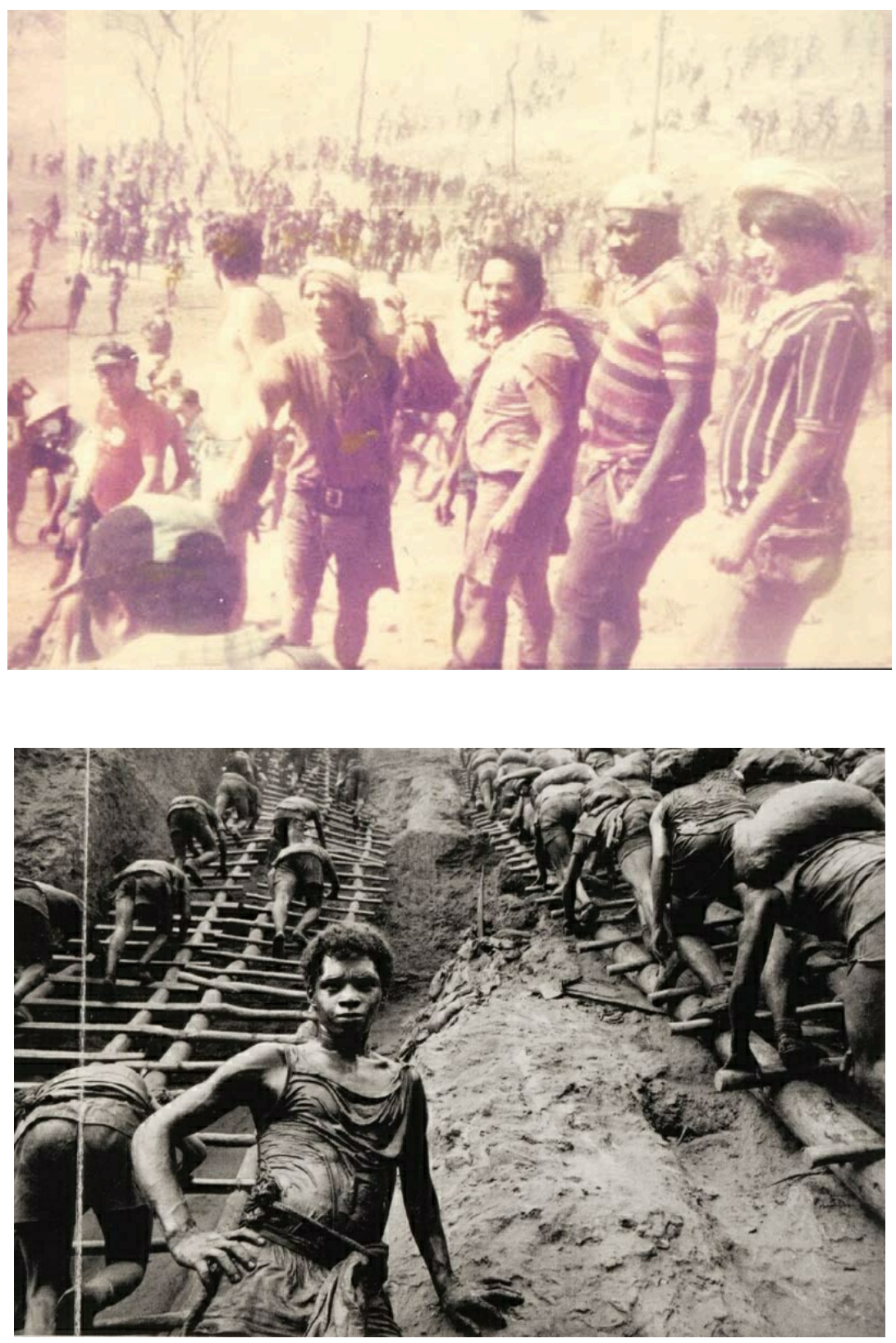

Figura 21 - (acima)

Neorealismo Trapalhão: filmado em Serra Pelada no auge do garimpo, o filme dos Trapalhões também capturava a realidade do formigueiro humano.

Fonte:

http://static.panoramio.com/photo s/large/31381878.jpg
Figura 22 - (abaixo)

A mina que não era encantada, por Sebastião Salgado.

Fonte:

http://tecnicoemineracao.com .br/wpcontent/uploads/2013/11/seba stiao-salgado-serra-pelada3.jpg 
Didi/Aragão (que aliás, se chama Curió no filme, em homenagem ao major que comandou a intervenção no garimpo, Sebastião Rodrigues de Moura, o Major Curió) é "amigo" de um indiozinho que obviamente se encontra em situação de alto risco no ambiente do garimpo. Os valores do filme oscilam entre o moralismo militarista dos heróis galãs e o amoralismo ganancioso dos heróis trapalhões.

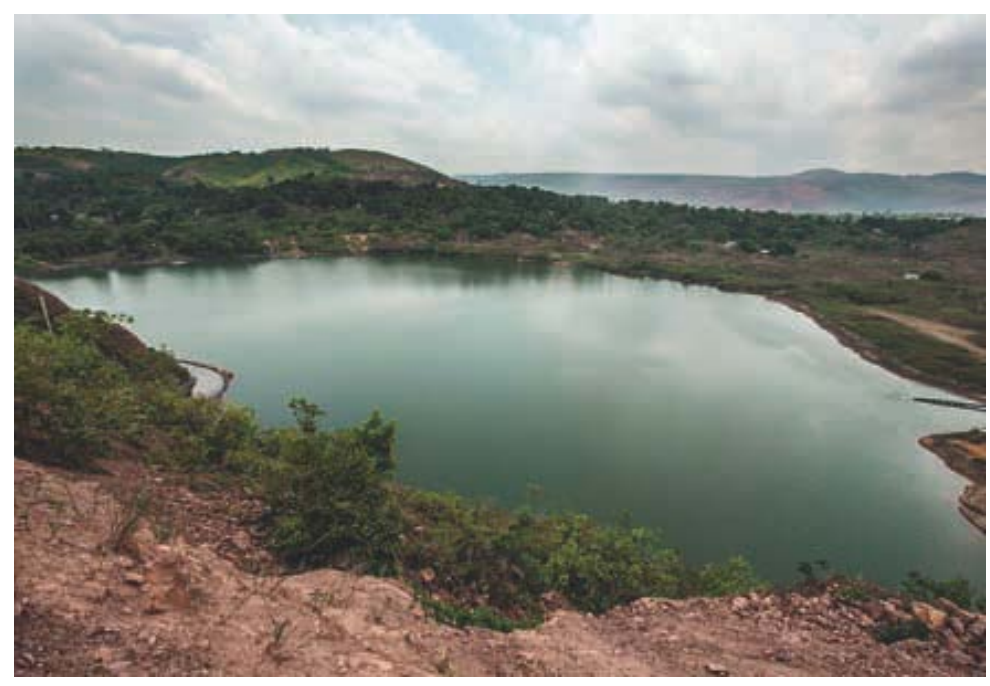

Figura 23 -

Sob as aguas tétricas desse lago, repousa a cava do garimpo. Em volta dele a vila de Serra Pelada no município de Curiópolis, habitada pelos remanescentes de Serra Pelada, que perseveram na prospecção de minérios na região.

Hoje em dia a cava do garimpo está submersa pelas águas escuras de um lago circundado por um povoado que está no topo dos inglórios rankings nacionais de casos de aids e tuberculose. Serra Pelada foi e ainda é a mina que não era encantada. Sua sombra assombra o videogame do Didi-garimpeiro, porque o Didi-garimpeiro é fruto de um filme que documentava aspectos da miséria do garimpo. Com o passar do tempo, no frigir dos ovos, depois de o garimpo se ter esgotado e de o videogame se haver tornado obsoleto, eis que percebemos na tarefa infinita - na tarefa de Sísifo daquele Didi que é atacado por uma avalanche de pepitas gigantescas na mina encantada; na tarefa sem fim daquele pixel garimpeiro que jamais sairá vivo daquela mina - um claro e cristalino paralelo com a situação de muitos dos garimpeiros retratados na suposta comédia dos Trapalhões. Alguns desses garimpeiros reais nunca saíram daquele buraco. Permanecem submersos no lago silencioso e doentio. Seus ossos jazem junto com as estimadas 280 toneladas de ouro, e as outras tantas de cobre, paládio e platina que habitam o subsolo do entorno. Essas reservas, jazidas abandonadas, recomeçam, agora, a ser exploradas, como reporta, no jornal O Estado de São Paulo, o jornalista Fernando Scheller (2013). O garimpo retrô-oitentista - como os videogames da época - experimenta o seu revival em pleno século XXI. 


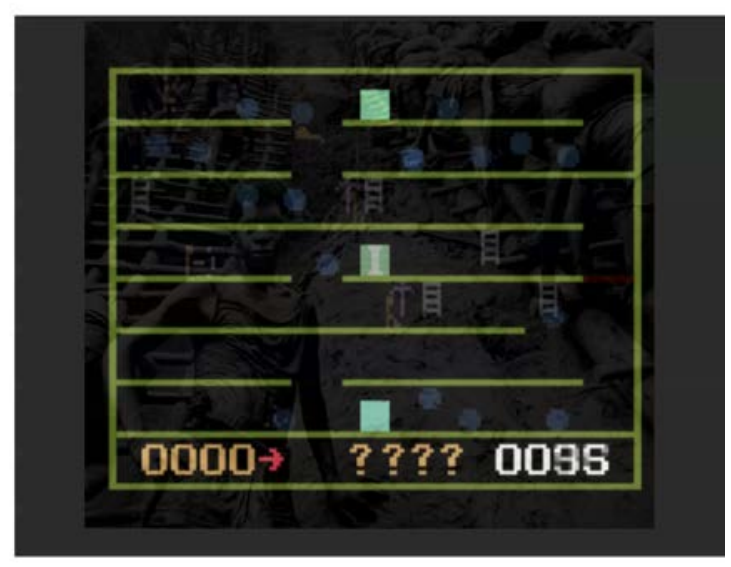

Figura 24 -

A sobreposição de algumas telas do Didi e a foto de Sebastião Salgado revela uma faceta inesperada do processo de localização deflagrado pela Philips Brasil.

O exemplo desse caso em estudo, desse muito particular caso pioneiro da localização de videogames no Brasil, nos ensina, afinal, que não existe maneira de se controlar as implicações de um programa de localização no longo prazo. A Philips, como vimos, inventou a indústria de localização do setor no Brasil. Sua síntese das localizações anteriores feitas noutras praças permitiu que oferecesse uma versão superior do Odyssey ao público brasileiro. Seu acordo com Renato Aragão foi, de fato, uma tacada de mestre. Didi na mina encantada foi o videogame certo, na hora exata, com a localização precisa de um produto que não apresentava nenhum empecilho para a obtenção da cidadania brasileira. O cartucho foi um grande sucesso, um destacado e memorável protagonista do nosso big video bang de 1983, "o ano dos videogames no Brasil”, como reza o título do livro de Marcus Chiado.

Todavia, esse bem sucedido processo de localização tem uma contrapartida. Todo processo de localização está inserido em um processo histórico e se revela apenas quando o confrontamos com essa sua historicidade. Na medida em que se vincula ao Didi-garimpeiro, a Philips, empresa transnacional holandesa, se vincula também ao tortuoso processo histórico do garimpo brasileiro. $\mathrm{O}$ fato é que o ciclo da corrida do ouro coincide com o ciclo do produto Odyssey, assim como é inegável que a Philips Brasil aproveitou-se do vínculo entre Aragão e Serra Pelada para localizar e promover o seu produto.

O Didi é, afinal, o vetor dessa contaminação: ele carrega para dentro da mina encantada do produto da Philips a realidade do garimpo capturada in loco no filme dos Trapalhões. O Odyssey era o "produto da recessão", pão e circo das famílias da classe média urbana, e sua associação com o formigueiro humano do garimpo revela a outra face da grande crise brasileira de 1980. O Odyssey remetia à faceta da crise tal como percebida pelas classes médias urbanas; onde o videogame era um produto substituto das viagens, jantares e casas de praia que os anos hiperinflacionários da década perdida haveriam de inviabilizar. Serra Pelada era a faceta da crise tal como experimentada pelos vastos contingentes de destituídos, que abandonavam seus lares nos mais diversos lugares do Brasil e se amontoavam na cava do garimpo, perseguindo o seu "sonho permanente de enriquecer de repente". Com o Didi na mina encantada, a Philips oferece um produto cultural que converge essas duas faces da crise, esses dois 
mundos de jogadores e garimpeiros. Inadvertidamente, a Philips constrói uma ponte sobre o abismo que separa esses dois mundos. Do ponto de vista histórico, ocorre também que a própria Philips fica associada ao drama do garimpo, contaminada, como dissemos. Essa associação 'negativa', essa mancha, é o preço da prospecção. O custo da localização.

Todos, explorando-se uns aos outros, exploravam a Serra Pelada: os garimpeiros, os capatazes, o exército, os humoristas, os cineastas, a Vale do Rio Doce, a Philips, eu mesmo, e tantos mais. Carregam consigo todos eles, todos nós, em alguma medida, sua/nossa parcela da responsabilidade no quadro caótico que invariavelmente circunda a exploração de minérios no Brasil - Serra Pelada apenas o melhor exemplo, a cava mais profunda. Naturalmente que a Philips teria preferido distanciar-se o quanto fosse possível da questão do garimpo. Não pode fazê-lo: é traída por seu próprio paratexto.

Na revista Odyssey Aventura, como já dito, supervisionada pela Philips, uma descrição do jogo é significativa: “Deslizamentos podem pegá-lo de surpresa. Enormes pedregulhos vão rolar constantemente, ameaçando a vida do Didi” (1983, p. 3). O “jogo do Didi” encenava, justamente, a principal causa de mortes no garimpo: "As mortes de garimpeiros por deslizamentos foram uma constante em Serra Pelada. Em 1983, no maior acidente desse tipo, 19 morreram” (Folha de São Paulo, 2002, s/p.). A mina encantada da Philips já estava, de início, confrontada à sua sombra, sua contraparte, assim como o trabalho de Sísifo do Didi garimpeiro em seu videogame, com a sua sucessão de mortes por deslizamentos, representava com frieza os riscos da prospecção na Cava. Nesse aspecto, o videogame ganha a mesma espécie de inadvertida dimensão documental que o filme dos Trapalhões. A despeito de seu sucesso, no curto prazo do ínfimo ciclo de vida de três ou quatro anos do Odyssey, o Didi-garimpeiro, vedete dessa estratégia de localização, é, sobretudo, um ícone da tragédia no garimpo.

Às margens do lago que se formou onde antes havia a cava do garimpo está o município de Curionópolis (corruptela do nome do personagem de Renato Aragão no filme, batizado em homenagem ao apelido do major da intervenção militar - também um agente do SNI nos anos da ditadura militar). O nome do município paga, portanto, um duplo e dúbio tributo: ao seu marechal patrono, antes araponga do SNI, hoje em dia prefeito e coronel do município que leva o seu nome; e também ao humorista que ajudou a imortalizar o garimpo com um filme e um videogame. Recentemente, um novo filme sobre Serra Pelada foi produzido. Seria o caso de se produzir um novo videogame?

Interessante imaginar que tipo de videogame poderia representar a Serra Pelada de hoje em dia, com seu lago sinistro e sua cidade quase fantasma, habitada pelos vivos. A cidade não tem água potável ou tratamento de esgoto (Estado de São Paulo, 2013, s/p.). O motor da economia local é o garimpo da mineradora canadense Colossus, situado a trinta quilômetros do lago. Trata-se de uma operação arriscada, em que os garimpeiros descem centenas de metros em um túnel escavado na rocha, atrás de ouro, cobre, paládio e platina. Estão sujeitos a desmoronamentos e a uma morte horrível por asfixia. Algumas coisas não mudaram. 
Tal cenário de filme de terror pede um videogame de terror como Silent Hill ou Dead Space. Serra Pelada só poderia ser representada por um videogame que se inscrevesse em um gênero que os críticos denominaram Survival Horror. O termo não costuma ser traduzido, mas designa exatamente o gênero adequado para traduzir em videogame os túneis escuros da mineradora e as águas sombrias do lago. Podemos imaginar o protagonista contemporâneo desse game, um garimpeiro-soldado, vestido com uma armadura, armado até os dentes, enfrentando os zumbis da cidade fantasma, comandados pelo agente secreto que virou prefeito. Ou, melhor um garimpeiro mergulhador, metido em um escafandro, com um foco de luz e um arpão de capitão Ahab, a se aventurar no lago sombrio, em busca do ouro submerso. Imaginemos que ele acaba de mergulhar naquelas águas. Estarão os sensores do seu escafandro assinalando traços do mercúrio que se usava no garimpo? Ele desce, e desce, até os cento e noventa metros mais profundos da cava. O que haverá por lá? Tesouros e riquezas? Os fantasmas dos garimpeiros mortos nos deslizamentos de décadas atrás?

O joystick vibra em nossa mão coletiva de jogador imaginário. Nosso avatar escafandrista atinge afinal o fundo da cava submersa. Em algum lugar há uma caverna. Dirigiremos nosso escafandrista para o interior dessa fenda desolada. Esperando por nós, estará um pixelado e primário boneco palito, um célebre remanescente da primeira geração de videogames. Brandindo como um maníaco a sua picareta, ele virá contra nós, bradando, entre os bips dos 8 bits, com uma voz sintética, o seu brado retumbante: "Os Pirataaaaaa."

Roberto Mário Schramm Jr. robertoschramm@yahoo.com Doutorando, Universidade Federal de Santa Catarina

\section{Referências bibliográficas}

BrAsiL. Lei n. 7.232, de 29 de outubro de 1984. Dispõe sobre a Política Nacional de Informática, e dá outras providências. Presidência da República, Casa Civil, Subchefia para Assuntos Jurídicos. Disponível: http://www.planalto.gov.br/ccivil_03/leis/17232.htm

ChIAdo, Marcus Vinicius Garett. 1983: O ano dos videogames no Brasil. São Paulo: Edição do Autor, 2011.

Didi na mina encantada. Programador: Ed Averett. Philips Brasil, 1983. 1 Cartucho com ROM. 
Even-Zohar, Itamar. Polysystem Studies. Poetics Today, vol. 11, n. 1, p. 1-268, 1990. FolHA de São Paulo. Primeira onda de garimpeiros extraiu 41 toneladas de ouro. 01. Dez. 2002. Caderno Brasil s/p. Disponível: http://www1.folha.uol.com.br/fsp/brasil/fc0112200223.htm

Kent, Steven. The ultimate history of videogames: from Pong to Pokemon. Nova Iorque: Three Rivers Press, 2001. (100, 94, 189-190)

MôniCA no Castelo do Dragão. Adaptação de 'Wonder Boy in Monster Land' por Estúdio TecToy. Brasil, Sega/Westone/TecToy/Maurício de Souza Produções, 1991. 1 Cartucho com ROM.

Os Trapalhões na Serra Pelada. Direção de J.B. Tanko, Roteiro de Gilvan Pereira. Rio de Janeiro: Renato Aragão Produções Artísticas/Europa Filmes, 1982. 1 DVD (88 min), color.

OdISSEY Aventura. São Paulo: Mauro Ivan Marketing Editorial/Philips Brasil, n. 1, 1983.

O2EM Odyssey2/Videopac+ Emulator. Emulador parav o Odissey2, desenvolvido por Dan Boris e Andre de la Rocha. Portado para Mac OSX por Richard Bannister. Disponível: http://www.bannister.org/software/o2em.htm

PICK, Axe Pete. Programador: Ed Averett. Magnavox/Philips, 1982. 1 Cartucho com ROM.

PyM, Anthony. The Moving Text: Localization, translation, and distribution. Amsterdam: John Benjamins Publishing, 2004. . Localization, Training, and Instrumentalization. Intercultural Studies Group, Universitat Rovira i Virgili, Tarragona, ES, Ago. 2013. Disponível: http://usuaris.tinet.cat/apym/on-line/training/2013_localization.pdf

Scheller, Fernando. Serra Pelada Renasce com novas tecnologias e com as suspeitas de sempre. O Estado de São Paulo. 02 nov. 2013. Caderno de economia, s/p. Disponível: http://economia.estadao.com.br/noticias/geral,serra-pelada-renascecom-novas tecnologias-e-com-as-suspeitas-de-sempre,169188e

Schiavoni, José. Odissey tem som e imagem de excelente qualidade. Folha de São Paulo. 23 nov. 1983. Caderno de Informática p.1

TOURY, Gideon. Descriptive Translation Studies and Beyond. Amsterdam: John Benjamins Publishing, 2012.

ViCENTE, Victor Emmanuel. 30 anos do Odyssey no Brasil. Jogos 80, n. 12, p. 48-53, Dezembro de 2013. Disponível: http://www.jogos80.com.br/edicoes/

Wonder Boy in Monster Land. Diretores: Ryuchi Nishizawa e Michishisto Ishizuka. Sega/Westone, 1987. 1 Cartucho com ROM. 